\title{
As razões e condições dos conflitos federativos na pandemia de Covid-19: coalizão partidária e desenho institucional ${ }^{1}$
}

\author{
Reasons and conditions for federative conflicts during the Covid-19 \\ pandemic: party coalition and institutional design
}

\begin{abstract}
Las razones y condiciones de los conflictos federativos en la pandemia de Covid-19: coalición de partidos y diseño institucional
\end{abstract}

\author{
Rubens Glezer ${ }^{2}$ \\ Escola de Direito de São Paulo da Fundação Getulio Vargas (São Paulo, SP, Brasil) \\ ORCID: https://orcid.org/0000-0002-4570-6280 \\ E-mail: rubens.glezer@fgv.br
}

\section{Resumo}

A crise sanitária provocada pela pandemia de Covid-19 no Brasil foi atravessada por uma crise política. Uma das facetas dessa crise política foi o conflito federativo, que opôs, de maneira explícita e constante, o presidente da República a governadores. A presente pesquisa dedicou-se a responder se essa oposição pode ter sido fomentada e viabilizada, pelo menos em parte, por características do federalismo brasileiro. Para isso, foi testada a hipótese de que os conflitos federativos entre presidente e governadores dependem da existência de (i) condições institucionais, (ii) baixos custos políticos e (iii) incentivos conjunturais para o enfrentamento. Ao examinar as normas constitucionais, a jurisprudência do Supremo Tribunal Federal e os aspectos fáticos da disputa entre presidente e governadores a partir de uma lente teórica fornecida por Jenna Bednar, a hipótese foi confirmada. $\mathrm{O}$ federalismo brasileiro tem mecanismos institucionais e políticos para prevenir e reagir a condutas oportunistas ilegítimas do presidente; mecanismos cuja compreensão está profundamente atrelada ao modo como o presidente estabelece suas coalizões partidárias.

\footnotetext{
GLEZER, Rubens. As razões e condições dos conflitos federativos na pandemia de Covid-19: coalizão partidária e desenho institucional. Suprema: revista de estudos constitucionais, Brasília, v. 1, n. 2, p. 395-434, jul./dez. 2021.

Doutor em Teoria do Direito pela Universidade de São Paulo (USP), Mestre em Direito e Desenvolvimento pela Fundação Getulio Vargas (FGV-SP), Pesquisador visitante na New York University (NYU). Professor da Graduação e Mestrado Profissional da FGV Direito SP e Coordenador do Centro de Pesquisa Supremo em Pauta, da FGV Direito SP. Currículo Lattes: http://lattes.cnpq.br/0076794265551843.
} 


\title{
Palavras-chave
}

Federalismo; Desenho institucional; Pandemia; Democracia; Coalizão partidária.

\section{Suimário}

1. Introdução. 2. O conflito aberto entre presidente e governadores na pandemia. 3. O federalismo brasileiro como uma barreira ao oportunismo federal. 3.1. O federalismo preventivo ao oportunismo concentrador. 3.2. O federalismo reativo ao oportunismo evasivo. 4. O sistema federativo responde ao Governo Bolsonaro. 5. Conclusão.

\begin{abstract}
The Brazilian public health crisis caused by the Covid-19 pandemic developed amidst a political crisis. One aspect of this political crisis is a persistent federative conflict, which explicitly opposes the president and governors. This research tries to answer if this opposition may have been bootstrapped, at least in part, by characteristics of Brazilian federalism. Hence, we hypothesized that such federative conflicts between president and governors depend on the existence of (i) institutional conditions, (ii) low political costs, and (iii) conjunctural incentives for confrontation. By examining constitutional norms, Supreme Court rulings, and the aspects of the dispute between president and governors through a theoretical lens provided by Jenna Bednar, the hypothesis was confirmed. Brazilian federalism has institutional and political mechanisms to prevent and react to illegitimate opportunistic conduct by the President; mechanisms which are deeply linked to the manner in which the President establishes his party coalitions.
\end{abstract}

\section{Keywords}

Federalism; Institutional design; Pandemic; Democracy; Party Coalition.

\section{Contents}

1. Introduction. 2. The open conflict between president and governors in the pandemic. 3. Brazilian federalism as a barrier to federal opportunism. 3.1. Preventive federalism to concentrating opportunism. 3.2. Federalism reactive to evasive opportunism. 4. The federative system responds to the Bolsonaro Government. 5. Conclusion.

\section{Resumen}

La crisis de salud pública brasileña causada por la pandemia Covid-19 se desarrolló en medio de la crisis política. Un aspecto de esta crisis política es un persistente conflicto federativo, que opone explícitamente al presidente y a 
los gobernadores. Esta investigación intenta responder si esta oposición pudo haber sido impulsada, al menos en parte, por características del federalismo brasileño. Por lo tanto, planteamos la hipótesis de que tales conflictos federativos entre presidente y gobernadores dependen de la existencia de (i) condiciones institucionales, (ii) bajos costos políticos y (iii) incentivos coyunturales para la confrontación. Al examinar las normas constitucionales, los fallos de la Corte Suprema y los aspectos de la disputa entre presidente y gobernadores a través de una lente teórica proporcionada por Jenna Bednar, se confirmó la hipótesis. El federalismo brasileño cuenta con mecanismos institucionales y políticos para prevenir y reaccionar ante la conducta oportunista ilegítima del presidente; mecanismos que están profundamente ligados a la forma en que el Presidente establece sus coaliciones partidarias.

\section{Palabras clave}

Federalismo; Diseño institucional; Pandemia; Democracia; Coalición de partidos.

\section{Índice}

1. Introducción. 2. El conflicto abierto entre presidente y gobernadores en la pandemia. 3. El federalismo brasileño como barrera al oportunismo federal. 3.1. Federalismo preventivo al oportunismo concentrador. 3.2. Federalismo reactivo al oportunismo evasivo. 4. El sistema federativo responde al Gobierno de Bolsonaro. 5. Conclusión.

\section{Introdução}

A crise sanitária provocada pela pandemia de Covid-19 no Brasil foi atravessada por uma crise política. Uma das facetas dessa crise política foi o conflito federativo, que opôs, de maneira explícita e constante, o presidente da República a governadores. Dada a raridade desse tipo de conflito durante a vigência da Constituição de 1988, a presente pesquisa dedicou-se a responder se essa oposição pode ter sido fomentada e viabilizada, pelo menos em parte, por características do federalismo brasileiro.

A partir de um levantamento bibliográfico preliminar a respeito de conflitos entre executivos nacional e estaduais ${ }^{3}$, foi possível formular a hipótese de que os

${ }^{3}$ Foram utilizadas na pesquisa a base de dados RVBI, Scielo, Jstor e Heionline. 
conflitos federativos entre presidente e governadores dependem da existência de (i) condições institucionais, (ii) baixos custos políticos e (iii) incentivos conjunturais para o enfrentamento. Mais especificamente, foi testada a hipótese de que, no Brasil, a Constituição fornece aos Estados condições para uma oposição política robusta ao governo federal. Além disso, que os custos políticos são altos para os governadores entrarem em conflito quando o presidente utiliza os mecanismos políticos de criação de consenso político abrangente, em especial pelo estabelecimento de uma coalizão partidária ampla e sólida. Essa coalizão partidária seria o principal instrumento de estabilização da relação com os governadores cujos partidos integram a coalizão durante a maior parte do período posterior a 1988. Na sua ausência, há baixos custos para os governadores se engajarem em conflito. Por último, a conduta oportunista do Governo Bolsonaro de ora tentar mitigar a autonomia dos Estados e ora se isentar da responsabilidade dos impactos negativos da crise sanitária (especialmente sobre a economia), deslocando-a para os governadores, criaria os incentivos para o conflito federativo.

Para testar essa hipótese, a coleta de materiais e dados foi organizada a partir da lente teórica fornecida por Jenna Bednar (2008), no livro "The Robust Federation”. A autora fornece as classificações e os critérios doutrinários para identificar justamente as condições, os custos e os incentivos para o conflito federativo. Nesse sentido, a reconstituição de fatos registrados em matérias jornalísticas, bem como a reconstrução da estrutura federativa pelas normas constitucionais em conjunto com a jurisprudência do Supremo Tribunal Federal (STF), são orientadas a verificar como é calibrada a relação entre a União e os Estados. Mais especificamente, tais dados serviram para identificar se, durante o período da pandemia, o Governo Bolsonaro tentou exercer o que a autora chama de "oportunismo federativo" e quais mecanismos o federalismo brasileiro detém para que os Estados se defendessem (e se defendam) desse tipo de investida ilegítima.

O presente artigo relata a confirmação da hipótese de pesquisa indicada anteriormente. Uma das características marcantes do Governo Bolsonaro é a incapacidade (ou resistência) de formar uma coalizão partidária sólida, da qual decorrem dificuldades de implementar sua agenda naquilo que depende da colaboração do Poder Legislativo. Como resultado, segundo argumentam Vieira, Glezer e Barbosa (2020), o Governo Bolsonaro exerce sua agenda pelo emprego de uma estratégia que mistura poderes exclusivos da presidência (de natureza legislativa, regulamentar, administrativa e política) com atos parainstitucionais. 
No campo das relações federativas, esse perfil de governo gera alguns tipos de risco específico para os Estados. É claro que há muitas outras relações federativas problemáticas, como Estados contra a União, Estado contra Estado ou alguns Estados que juntamente com a União se impõem contra uma minoria de Estados ${ }^{4}$. Contudo, o presente artigo enfoca a relação entre a União e os Estados. Nesse campo, é possível que se estabeleça um oportunismo federativo "concentrador", quando a União tenta diminuir a autonomia dos Estados, normalmente pela invasão de sua competência ou por represálias financeiras. Porém, também é possível que o oportunismo federativo seja evasivo, ao deslocar os méritos eleitorais, imputando os resultados negativos aos governadores e assumindo os resultados positivos para si (BEDNAR, 2008). O que a pesquisa constatou é que essa estratégia de implementação da agenda limita severamente as condições de oportunismo federativo concentrador, mas potencializa o seu oportunismo federativo evasivo pelo Governo Bolsonaro.

Isso porque a ausência de uma coalizão partidária sólida enfraquece a capacidade do Governo Bolsonaro de invadir competências estaduais, pois não pode contar com o apoio do Poder Legislativo para superar as altas barreiras impostas pelo sistema de proteção da autonomia dos Estados. Sua liberdade para confrontar essa autonomia por decisões administrativas e políticas é bastante restrita. Além disso, o presidente tem poucas ferramentas para minar a autonomia financeira dos Estados. Contudo, essa ausência de coalizão lhe dá amplitude de ação para maximizar o seu benefício eleitoral. Sem as amarras de lealdade partidária, um presidente como Bolsonaro pode manter sua base eleitoral constantemente engajada pela disputa com governadores opositores. Nesse contexto, os governadores têm incentivos para disputar com o governo federal os resultados eleitorais, pela preservação de seu mandato, reputação de seu partido ou, possivelmente, para futura disputa presidencial. Esse antagonismo é frutífero para um governo federal disposto a maximizar os seus benefícios eleitorais sem a necessidade de negociar com outros partidos. Nesse âmbito, os governos estaduais não dispõem de ferramentas institucionais para controlar a agenda do governo federal. Porém, dada a repartição de competências do federalismo cooperativo brasileiro, os governadores podem competir com o governo federal (apresentando políticas alternativas) ou mesmo prejudicar a implementação de políticas federais em determinadas áreas, especialmente no que se refere às políticas de saúde e educação.

${ }^{4}$ Baker (2001, p. 951-974) chama esse problema de "horizontal aggrandizement". 
Sendo assim o sistema federativo brasileiro é dotado de diversos mecanismos institucionais de natureza estrutural e política para proteger os governos estaduais, ao manter as condições de equilíbrio dessa relação entre a União e os Estados. Além disso, o sistema constitucional concede ao Supremo Tribunal Federal um papel privilegiado no controle de conflitos federativos. Por meio de um largo mandato constitucional e diferentes vias processuais, diversos atores têm a capacidade de instigar o Supremo a coibir abusos por parte dos entes federados, evocando transgressões à repartição constitucional de competências federativas. Em razão da amplitude e equivocidade dos termos dessas listas de repartição de competências, o STF tem ampla liberdade de intervenção nos conflitos federativos. Nesses casos, a jurisprudência do Supremo Tribunal Federal tem sido protetiva em relação ao equilíbrio das relações federativas, ao manter as condições para que os governadores compitam politicamente com o presidente em caso de oportunismo eleitoral.

Para apresentar esses resultados, a primeira seção deste artigo fornece um panorama fático sobre como o Governo Bolsonaro gerou incentivos para que os governadores se engajassem em um conflito explícito com o presidente durante a pandemia de Covid-19. A segunda seção apresenta os referenciais teóricos da pesquisa e explora os detalhes de desenho institucional do federalismo brasileiro, aptos a proteger os Estados de investidas ilegítimas pelo governo federal. $\mathrm{Na}$ terceira seção, são fornecidos exemplos práticos de como o sistema federativo brasileiro manteve a capacidade de competição entre os Estrados e a União calibrados durante a pandemia de Covid-19, com destaque para a atuação do Supremo Tribunal Federal. Em seguida, é apresentada a conclusão da pesquisa.

\section{O conflito aberto entre presidente e governadores na pandemia}

O Governo Bolsonaro é atravessado por constantes conflitos com os governadores. Esse antagonismo foi construído a partir de reiterados discursos de competição. Essa competição parece ser parte de sua faceta populista, seja para implementar sua agenda sem necessidade de consenso com outros agentes, seja para manter sua base eleitoral em mobilização permanente. ${ }^{5}$ Essa

\footnotetext{
${ }^{5}$ Para fins deste artigo, entende-se por líder populista aquele que (i) se apresenta como o único representante legítimo da vontade popular nacional, com o intuito de marcar seus opositores como falsos representantes (MUDDE, 2017), bem como (ii) tem uma hostilidade às instituições política, seja para fugir dos limites e controles institucionais, ao
} 
necessidade de mobilizar a base eleitoral de forma permanente exige que o presidente Bolsonaro apresente a ela constantemente seus "inimigos", para serem combatidos e criticados. Por vezes o alvo é a imprensa, por outras o Congresso Nacional, reiteradas vezes o Supremo Tribunal Federal e, claro, os govenadores com posturas divergentes da sua.

Como presidente e governadores são eleitos no mesmo processo eleitoral, é usual a aliança entre candidatos desses dois níveis federativos. Como regra, essas alianças eleitorais seguem a lógica da coalizão partidária. Porém, como Bolsonaro não teve uma coligação partidária durante o período eleitoral e concorreu por um partido pequeno e sem tradição, as alianças de campanha foram guiadas por interesses conjunturais. Mais da metade dos governadores eleitos em 2018 (15 dentre 27) foram aliados em campanha eleitoral de Bolsonaro (VILELA, 2018). Contudo, logo no início de 2019, alguns dos aliados eleitorais se tornaram ferrenhos opositores, em especial os governadores de São Paulo, João Dória, e do Rio de Janeiro, Wilson Witzel. Outros se elegeram justamente sob a insígnia de oposição a Bolsonaro, como o governador do Maranhão, Flávio Dino. Porém, muitos outros governadores passaram a se distanciar progressivamente de Bolsonaro ao longo da primeira metade de seu mandato. Em abril de 2020, vinte governadores escrevem uma "Carta aberta à sociedade brasileira em defesa da democracia”, com críticas à postura de Bolsonaro (G1, 2020).

Desde o início do mandato, Bolsonaro estimulou a rivalidade com governadores por meio da disputa pela autoria ou pelo protagonismo na inauguração de obras realizadas nos Estados (PITOMBO, 2019; FARIAS, 2020; ESTADÃO CONTEÚDO, 2020b). Suas declarações reforçam o atrito político, a exemplo da realização de piada homofóbica após visita ao Maranhão (UOL, 2020), das reações irônicas ao andamento da investigação contra o governador do Rio de Janeiro (MAZUI, 2020) e do compartilhamento, pelo Senador Flávio Bolsonaro, de vídeo que acusa o governador da Bahia de estar envolvido na morte de miliciano (CORREIO DO POVO, 2020). Em sua retórica, já atribuiu a governadores a responsabilidade pela execução de políticas públicas ou resolução de crises, com o intuito de eximir-se de responsabilidade. Em meio a pedidos de redução do preço de combustíveis, prometeu zerar o imposto federal, desde que os governadores se dispusessem a zerar a tributação estadual (BARBOSA; SOARES, 2020). 
Governadores reagiram com críticas, dada a inviabilidade prática de realizarem essa isenção (MARTELO, 2020).

A pandemia de Covid-19 expandiu as condições para esse antagonismo federativo e aumento de condutas oportunistas pelo governo federal. A postura política do Governo Bolsonaro em relação à pandemia de Covid-19 foi a de minimizar sua relevância. Endossou publicamente a hidroxocloroquina como medicamento eficaz ao tratamento e ordenou que o Exército produzisse o remédio em larga escala. A campanha resultou em escassez do medicamento nas farmácias no início da pandemia e, com a comprovação da ineficácia do produto ao longo dos meses, levou ao Exército a possuir um estoque mais alto do que sua capacidade de distribuição (CANCIAN, 2020). Bolsonaro se manteve hostil às políticas de isolamento social e de restrição às atividades econômicas. Sua postura levou, durante a pandemia, à demissão de dois ministros da saúde com formação médica e, em seguida, à manutenção do cargo vago por quatro meses. Durante esse período, um general sem formação médica nem experiência na área da saúde assumiu interinamente o posto, para ser efetivado apenas em setembro de 2020 (BERTONI, 2020). O general foi exonerado poucos meses após sua efetivação no cargo, e o Ministério da Saúde recebeu seu quarto ocupante, um médico cardiologista, a partir de março de 2021 (MOTTA, 2021).

Enquanto as políticas de isolamento social e restrição à atividade econômica ficaram sob a responsabilidade dos governadores, Bolsonaro afirmou que governadores deveriam pagar por encargos trabalhistas de dias parados em razão da quarentena (MAIA; TRINDADE, 2020) e atribuiu a governadores a culpa pelas mortes e pela crise econômica (GRILLO, 2020). A mídia denunciou a existência de uma ala no gabinete de crise destinada a monitorar e mapear a posição dos governadores a partir de seu grau de alinhamento com a retórica do governo a respeito das medidas de combate ao coronavírus (BRONZATTO, 2020). Ao longo da pandemia, Bolsonaro criticou o fechamento de escolas e comércio em pronunciamento em rede nacional (BBC NEWS, 2020), apelou para que empresários fizessem pressão a governadores para a reabertura econômica (BARBOSA; FERNANDES; SOARES,., 2020) e comparou a política de isolamento social do Maranhão à crise política e econômica na Venezuela (G1 MA, 2020).

Além disso, antagonizou com João Dória uma disputa a respeito da futura obrigatoriedade da vacinação contra o coronavirus (DANTAS, 2020) e obtenção de verbas para a compra de um lote de vacinas Coronavac, desenvolvidas pelo Instituto Butantan, de São Paulo, em parceria com a China (ESTADÃO 
CONTEÚDO, 2020a). Em meio à disputa, a Agência Nacional de Vigilância Sanitária (Anvisa) determinou a suspensão temporária dos estudos clínicos para elaboração da vacina sem consultar o Instituto Butantan (PORTO, 2020), após um óbito por suicídio de um dos voluntários que se submetia ao estudo (PEREIRA; MAZIEIRO, 2020). Antes da autorização para a retomada dos estudos clínicos, o presidente se manifestou da seguinte maneira em uma rede social: "Morte, invalidez, anomalia. Esta é a vacina que o Doria queria obrigar a todos os paulistanos tomá-la. O Presidente disse que a vacina jamais poderia ser obrigatória. Mais uma que Jair Bolsonaro ganha." (grifo nosso) (GAVIOLI, 2020). A disputa pela vacinação seguiu adiante, com mais incidentes do que seria adequado e possível narrar nesta pesquisa. Porém, basta pontuar que, em outubro de 2021, mesmo após uma ampla adesão da população à vacinação, Bolsonaro insinuou publicamente que a vacinação contra a Covid-19 implicaria algum tipo de vulnerabilidade à Síndrome da Imunodeficiência Adquirida (AIDS) (ROCHA, 2021).

Como será apresentado nas próximas seções, coerente com a faceta populista do Governo Bolsonaro, o presidente tentou invadir as competências dos Estados, com interferências sobre as políticas de isolamento social e retaliações de ordem financeira. Além disso, endossou medidas sem nenhum respaldo da comunidade científica, culpou os governadores pela crise econômica e antagonizou as iniciativas estaduais de criação de vacina. As seções a seguir detalham as características institucionais do federalismo brasileiro que tentam proteger os Estados desse tipo de conduta por parte do governo federal.

\section{O federalismo brasileiro como uma barreira ao oportunismo federal}

Um sistema federativo bem calibrado é capaz de impor limites robustos para a implementação de ataques oportunistas entre os entes federativos. Essa calibragem adequada decorre da existência de uma estrutura capaz de prover um equilíbrio de permanente colaboração competitiva entre os entes federativos. Um sistema no qual Estados não tiverem condições de controlar o Poder Executivo nacional torna mais simples o exercício imoderado de poder por alguém com propensões populistas ou autoritárias (BEDNAR, 2008).

A conexão entre federalismo e proteção democrática já estava presente em Os Federalistas, especialmente nos textos de Madison (GREENE, 1994). No artigo $\mathrm{n}^{\circ}$ 51, os benefícios de um Estado federado para lidar com os riscos do 
autoritarismo são abordados de forma análoga ao esquema de separação de poderes: como uma proteção ante os abusos do Estado e também de maiorias violentas. Em primeiro lugar, a dispersão do poder entre entes federados estabelece barreira adicional à concentração de poderes nas mãos do presidente. Em segundo lugar, a divisão da população em diferentes comunidades gera um obstáculo à criação de uma grande maioria violenta contra as minorias (MADISON et al., 2008, p. 258). Esse segundo problema é apresentado de forma mais direta no artigo no 10 , no qual Madison esclarece o tipo de conduta conflitiva que o preocupa: "[cidadãos] unidos por uma ação comum passional, ou por interesse, contrário aos direitos de outros cidadãos, ou aos interesses permanentes e coletivos da comunidade”. Madison considera essa propensão à violência tribal do "facciosismo" como um aspecto próprio da natureza humana, que não tem como ser suprimido sem a aniquilação da própria liberdade e que, portanto, não teria como ser prevenido em uma democracia, mas apenas mitigado. Entre as diferentes formas de "facciocismo", Madison identifica uma como a mais perigosa: aquela promovida por uma maioria instalada no governo. Para Madison (2008, p. 51-54), o federalismo coloca barreiras a esse "facciosismo" majoritário e governamental ao criar divisões entre a população, que tornariam difícil a coordenação desse tipo de paixão majoritária violenta: no mínimo pela oportunidade de criar diversos espaços com agentes que têm os mais diversos interesses.

Contudo, a literatura contemporânea tem enfatizado o quanto essa relação entre federalismo e democracia depende das estruturas concretas de sua operação (BÉDARD-RUBIN, 2019; BULMAN-POZEN, 2012; KAMENA JR, 2001; MILLHISER, 2016). Como Obydenkova e Sweden observaram em seu estudo comparativo entre a Rússia e outros países da Europa Ocidental, são as características e o desenho institucional específico do federalismo de cada país que servirão para fomentar a democracia ou estabilizar regimes autocráticos (OBYDENKOVA; SWEDEN, 2013; STARODUBTSEV, 2017). Mais recentemente, Landau, Wiseman e Wiseman argumentam que a principal virtude do federalismo norte-americano é dar autonomia para as burocracias estaduais, ao judiciário e a agentes policiais estaduais, bem como a eleições estaduais. Apesar de ser um artigo com exortações à análise de desenhos institucionais específicos - e suas vantagens para a contenção de líderes despóticos - os autores avançaram pouco em relação ao insight inicial de Madison (LANDAU; WISEMAN; WISEMAN, 2020).

Algo distinto foi apresentado por Jenna Bednar (2008), em seu The Robust Federation. Esse livro apresenta uma forma mais específica de mapear a relação entre aspectos concretos de um sistema federativo e os limites a investidas 
populistas e autocráticas. Em especial, a constitucionalista aborda o problema federativo como uma dificuldade de ação coletiva e, a partir disso, cria uma tipologia de violações ao empreendimento federalista. O comportamento oportunista pode dizer respeito tanto a questões alocativas de poder quanto distributivas de recursos ou ainda a questões eleitorais. Na relação entre a União e Estados, Bednar (2008) indica que o oportunismo se dá por um tipo de "invasão" ou de "fuga". Como uma leve adaptação em como a autora apresenta suas ideias, mas preservando a sua contribuição, podemos dizer que o conflito federativo entre a União e os Estados traz sempre o risco de (i) invasão de competências, de recursos orçamentários ou de crédito eleitoral ou (ii) fuga de responsabilidades, de custo financeiro ou de custo eleitoral (BEDNAR, 2008, p. 189-205).

A tipologia de Bednar (2008) sobre comportamentos oportunistas no sistema federativo é instrutiva para analisar como as relações entre entes federativos são limitadas por mecanismos de diferentes naturezas. O oportunismo que chamamos de concentrador tende a se manifestar predominantemente pelas invasões de competência e de recursos orçamentários. Por meio de ações dessa natureza, o presidente tem a capacidade de, por exemplo, tentar implementar ilegitimamente sua agenda em escala nacional, enquanto premia aliados e pune a oposição. O oportunismo que chamamos de evasivo, conectado com o favorecimento dos grupos de apoio e a mobilização da base eleitoral às custas da oposição por meio de um discurso idealizado de nação e favorável ao "senso comum", tende a se manifestar por meio dos mecanismos que permitem ao presidente, por exemplo, imputar resultados negativos a governadores e reclamar os positivos para si, enquanto deixa de cumprir com suas obrigações relativas a políticas públicas.

No caso do Governo Bolsonaro, a referida tipologia será útil para identificar por que o federalismo brasileiro oferece mecanismos robustos de prevenção ao oportunismo concentrador e, sob certas condições, reativo ao oportunismo evasivo.

\subsection{O federalismo preventivo ao oportunismo concentrador}

Um governo federal autocrático tenderá ao oportunismo de "invasão" das competências administrativas e de recursos financeiros. Esse é o tipo de oportunismo intergovernamental mais conectado com tentativas de concentração de 
poder. Os mecanismos federativos de controle são primordialmente estruturais, mas também judiciais com possível atuação do Supremo Tribunal Federal.

Landau, Wiseman e Wiseman (2020, p. 1205-1209), por exemplo, tratam da relevância da autonomia das burocracias e dos aparatos de vigilância estatal. Essa autonomia opera como uma barreira que um líder populista ou autoritário teria que derrubar para implementar sua agenda. Como notam Ginsburg e Versteeg (2020, p. 48), a autonomia burocrática significa que a implementação de políticas federais depende de algum grau de cooperação voluntária do corpo administrativo. Em um federalismo cooperativo, a atuação local pode frustrar ou atrapalhar a agenda federal. Contudo, Bednar (2008, p. 87) apresenta com clareza que a proteção federativa precisa ser compreendida de maneira mais sistemática. Em suas palavras, é preciso verificar se o conjunto de mecanismos existentes é complementar, e até mesmo redundante, ao lidar com a amplitude dos riscos de conduta oportunista.

O mapeamento do desenho institucional brasileiro indica que o federalismo brasileiro dotou os Estados de robusta autonomia administrativa e estabeleceu limites severos à discricionariedade do presidente de discriminação entre entes federativos, até mesmo com desincentivos robustos à utilização de poderes de exceção. Essa autonomia estrutural robusta fornece aos Estados um potencial relevante de resistência ao oportunismo concentrador do governo federal.

Partindo das garantias mais básicas, cada Estado tem o poder de criar e organizar sua própria burocracia que, em geral, tem alto grau de independência no processo seletivo (via concurso público) e exercício da função (em razão da estabilidade). A livre escolha de funcionários é destinada para cargos de confiança, sensíveis para o exercício do poder político do Estado ou funções de chefia. Os Estados mantêm o seu próprio Poder Judiciário, Ministério Público e Polícia Militar, responsáveis por aplicar a legislação regional e federal. Além disso, os Estados produzem suas próprias leis, nos termos de suas Constituições estaduais, produzidas por deputados estaduais que ocupam a assembleia legislativa por mandato de quatro anos, em período idêntico ao dos governadores. Porém, tanto o Judiciário quanto o Ministério Público e a Polícia Militar têm, na prática, uma ampla autonomia em relação ao governador e, por esse motivo, podem - em maior ou menor parte - se alinhar ao governo federal e minar o governo estadual. 
Os Estados também são dotados de razoável segurança financeira, ainda que dependam centralmente do orçamento do governo federal. Enquanto Estados têm autonomia sobre sua burocracia fazendária para recolher impostos, somente podem recolher aqueles estabelecidos pela Constituição Federal, de acordo com parâmetros definidos pelo Senado Federal (CF/1988, art. 155). Essa autonomia orçamentária não implica independência financeira. Pelo contrário, os Estados e os Municípios são largamente dependentes da transferência de recursos do governo federal (ARRETCHE, 2019, p. 57). Contudo, podem contar com a transferência desses recursos, independentemente da conjuntura política. Nos termos de Marta Arretche (2019, p. 70), "prefeitos e governadores contam com recursos da União independentemente de lealdades partidárias ou comportamento parlamentar". Isso ocorre porque a Constituição estabeleceu um sistema de transferência obrigatória a Estados e Municípios que consome uma parcela expressiva dos tributos federais (CF/1988, art. 159). Além disso, uma boa parte das transferências é disponibilizada por meio de normas que, visando incentivar uma determinada política pública, transferem a verba aos Estados que cumprirem com os requisitos legais. Até mesmo as operações de crédito da União aos Estados são realizadas conforme disposições legais ${ }^{6}$. A transferência discricionária por parte do presidente da República é de relevância marginal. O Gráfico 1 apresenta a comparação de volume entre 2011 e 2019.

\footnotetext{
${ }^{6}$ BRASIL. Decreto n 10.282 , de 20 de março de 2020. Regulamenta a Lei no 13.979, de 6 de fevereiro de 2020, para definir os serviços públicos e as atividades essenciais. Brasília: Presidência da República, [2021]. Disponível em: http://www.planalto.gov.br/ccivil_03/_ato2019-2022/2020/decreto/D10282.htm. Acesso em: 25 nov. 2021. BRASIL. Congresso Nacional. Senado Federal. Resolução no 43, de 21 de dezembro de 2001. Dispõe sobre as operações de crédito interno e externo dos Estados, do Distrito Federal e dos Municípios, inclusive concessão de garantias, seus limites e condições de autorização, e dá outras providências. Brasília: Senado, [2021]. Disponível em: https://legis. senado.leg.br/norma/582604. Acesso em: 25 nov. 2021.
} 


\section{Gráfico 1 - Natureza orçamentária da transferência de verba da União aos Estados}

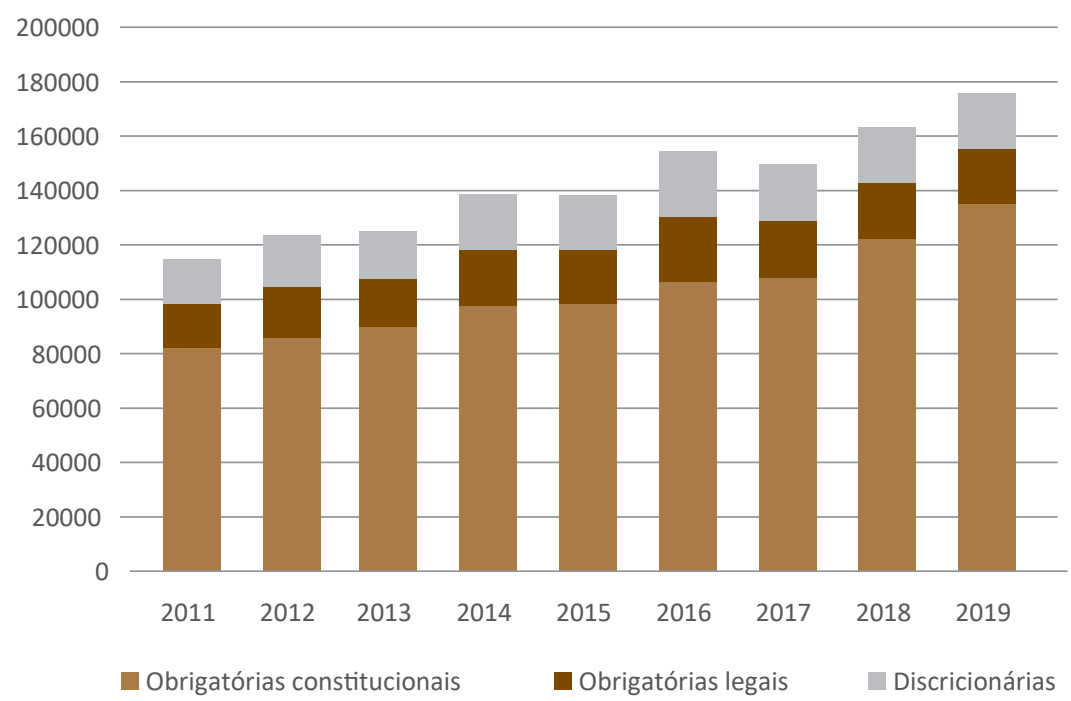

Fonte: Elaboração própria, a partir de dados de transferências da União obtidos no site do Tesouro Nacional.

Mesmo dentro das transferências discricionárias, há nuances a serem capturadas. Dentre tais transferências, a chamada de "voluntária” - mobilizada com ampla liberdade política - corresponde a uma parcela ínfima dos valores totais. Em 2019, por exemplo, 89\% dos quase 176 bilhões de reais transferidos aos Estados foram destinados por transferências obrigatórias de natureza constitucional e legal. Dos aproximadamente 20 bilhões de reais transferidos por despesa discricionária, apenas 720 milhões foram transferidos por transferência voluntária. Em outras palavras, as transferências realizadas exclusivamente pela vontade política do presidente correspondem a $4 \%$ das transferências discricionárias e a $0,4 \%$ do total de verbas transferidas. ${ }^{7}$

Isso não implica dizer que tais verbas são irrelevantes. Esses dados apontam que esses repasses discricionários não são cruciais para as finanças dos Governos Estaduais, em situações de normalidade. Silva (2015, p. 58) chama a atenção para a possibilidade de que tais transferências sejam úteis para a manutenção da coalização partidária no que se refere, especialmente, à negociação com senadores, por exemplo.

\footnotetext{
Disponível em: https://www.tesourotransparente.gov.br/. Acesso em: 27 nov. 2021.
} 
Com isso, o federalismo brasileiro estabelece um sistema projetado para a proteção financeira dos Estados, pelo estabelecimento de um modelo no qual há pouco espaço para que tais verbas sejam utilizadas como moeda de troca política (CF/1988, art. 160, parágrafo único). Há, no entanto, uma exceção a essa regra. A Constituição foi reformada em 2000 para dar à União a possibilidade de condicionar a entrega desses recursos aos Estados ao pagamento de suas dívidas com a própria União ou que envolvam garantia da União (CF/1988, art. 160, parágrafo único, I). Contudo, conforme será explorado em seção específica, o Supremo Tribunal Federal realizou uma série de restrições e condicionantes a respeito dessa possibilidade de retenção de verbas constitucionais.

Os Estados continuam protegidos pelo federalismo brasileiro mesmo em contextos extraordinários. O presidente pode interferir diretamente na administração de um Estado-membro caso seja decretada intervenção federal. A intervenção federal somente pode ser decretada sob hipóteses específicas, como "repelir invasão estrangeira" ou encerrar "grave comprometimento da ordem pública" (CF/1988, art. 34). O decreto precisa ser aprovado pelo Congresso Nacional e por órgãos opinativos com membros da sociedade civil (CF/1988, art. 90). Além disso, a intervenção não pode se manter se a causa da intervenção já tiver sido resolvida (CF/1988, art. 35). Durante esse período de intervenção, a Constituição Federal não pode ser emendada, bloqueando a possibilidade de mudanças políticas robustas durante esse momento de instabilidade federativa (CF/1988, art. 60, $\$ 4^{\circ}$ ).

Por último, seria possível imaginar que os Estados poderiam ser pressionados por meio dos mecanismos para criação ou supressão de Estados. No entanto, a modificação da estrutura federativa depende de norma federal aprovada com quórum super majoritário, legislação local e consulta à população local. A Constituição estabeleceu uma condição especial de proteção para esse modelo de equilíbrio federativo, ao estabelecer que a forma federativa do Estado é cláusula pétrea, ou seja, qualquer emenda constitucional voltada a flexibilizar esse sistema pode ser declarada inconstitucional pelo Supremo Tribunal Federal.

Com isso, o modelo federativo brasileiro é capaz de prevenir tentativas do governo federal de interferir com sua burocracia, seu equilíbrio orçamentário ou no próprio desenho federativo, com limitações robustas sobre a discricionariedade administrativa do presidente da República. Essas características de insulamento burocrático, eleitoral e financeiro tornam o sistema federativo brasileiro vocacionado a proteger os Estados federados de ações autocráticas 
do governo federal. Essa proteção é, em larga medida, realizada por meio de mecanismos preventivos, que dificultam ataques à autonomia estadual. Esses mecanismos de proteção atuam de maneira muito diferente em relação a condutas de natureza populista.

\subsection{O federalismo reativo ao oportunismo evasivo}

Como dito, um sistema federativo será mais calibrado na medida em que os Estados forem dotados de condições reais de controlar as decisões políticas tomadas pelo governo federal ou, pelo menos, de competir com elas. Um governo federal oportunista tenderá a maximizar o seu benefício eleitoral, assumindo o mérito de outros governantes, fugindo da responsabilidade dos seus atos, deslocando sua responsabilidade para outros entes federativos, ou impondo sua agenda política aos outros entes federativos. Tais medidas podem se dar tanto no âmbito meramente discursivo quanto na promulgação de normas jurídicas ou na ação (ou omissão) administrativa. Esse é o tipo de oportunismo federativo mais conectado com tentativas de mobilização constante da sua base eleitoral. Os mecanismos federativos de prevenção operam como um conjunto complexo de natureza estrutural e política, com suporte de mecanismo judicial pelo STF.

Os mecanismos de natureza estrutural estão embutidos em nosso federalismo cooperativo, extensamente detalhado na Constituição de 1988. Em termos administrativos, a Constituição discrimina os serviços e as políticas que são planejados e executados apenas pela União, daqueles nos quais os Estados executam em conjunto com a União e também com os Municípios (CF/1988, arts. 21 a 23). Em termos legislativos ocorre algo semelhante, a Constituição lista temas cuja normatização deve ser uniforme em todo o território nacional e lista outros sobre os quais a União deve se limitar a produzir normas gerais, cuja especificidade pode ser adaptada por cada Estado (CF/1988, arts. 22 a 24). No caso de temas de responsabilidade compartilhada, a ausência de legislação federal não impede a regulação estadual. No mais, Estados somente detêm exclusividade sobre as competências que não foram repartidas na Constituição (CF/1988, art. 25, $\left.\$ \$ 1^{\circ}-4^{\circ}\right)$. Essa divisão por temas e também pela oposição entre normas gerais e específicas dá ampla margem para disputas interpretativas, porque, em diversos casos, um determinado serviço ou legislação poderia ser razoavelmente incluído em qualquer uma dessas listas ou classificações. Nesse sentido o sistema estabeleceu um papel central ao Supremo Tribunal Federal para organizar na prática essa divisão teórica de competências (SILVA, 2010). 
Essa estrutura de federalismo cooperativo impõe à União um dever robusto de coordenação e consenso. O federalismo cooperativo exige esforços de coordenação da União, "mediante normatização, indução e financiamento" de políticas nacionais de "expansão de políticas públicas e do combate à desigualdade" (ABRUCIO et. al, 2020). Quando a união se nega a exercer seu papel de coordenação, há aumento do conflito federativo e da desigualdade entre os entes, bem como "desperdício de recursos, sobreposição de ações, redução dos ganhos de escala [..] e prejuízo à garantia dos direitos sociais [...]”, especialmente em face de problemas complexos de natureza intergovernamental (ABRUCIO et al., 2020, p. 672-673). Quando a União não cria consensos, os governos estaduais podem impor severas resistências aos planos do governo federal, por meio de ações contrárias e disputas de natureza administrativa e política (BULMANPOZEN; GERKEN, 2008) ou judicial (BULMAN-POZEN, 2012) .

Os mecanismos de natureza política decorrem justamente das condições envolvendo coordenação e consenso. Em razão da natureza altamente consensual do sistema político brasileiro, a capacidade de coordenação e de consenso do presidente da República depende da formação de uma coalização partidária ampla e sólida (VIEIRA; GLEZER; BARBOSA, 2020). É a negociação bem-sucedida com os partidos políticos majoritários que permite a implementação de sua agenda no Congresso Nacional (CHEIBUB; FIGUEIREDO; LIMONGI, 2009) e - podemos acrescentar - que dita o grau de cooperação dos governadores.

Como mapeado por Arretche e Schlegel (2014), sob o aspecto institucional, os governadores têm poucos espaços institucionais para interferir diretamente na formulação de opções políticas federais. Sendo assim, os partidos políticos são o espaço de intermediação entre interesse dos Estados e o poder federal, e sua relação é dada pela coalizão presidencial. As coalizões são estabelecidas antes do período eleitoral, como uma estratégia que permite que as campanhas estaduais impulsionem as nacionais, para que os candidatos a presidente tenham projeção ora de seu Estado natal (LIMONGI; CORTEZ, 2010). Durante a presidência, a lógica da coalizão partidária prepondera nas votações do Congresso Nacional, em detrimento de interesses locais (ainda que as coalizões de governo sejam distintas das eleitorais). Como indicam Cheibub, Figueiredo e Limongi

\footnotetext{
${ }^{8}$ Bulman-Pozen (2012) argumenta que Estados que resistem à intrusão do governo federal em sistemas de federalismo cooperativo tendem a fazê-lo enfatizando que as normas estaduais estão de acordo com as diretrizes do Congresso ou que o governo federal extrapola os poderes estabelecidos pelo Congresso e, com isso, reforçam a lógica de separação de poderes.
} 
(2009): "os legisladores dos partidos governistas tendem a votar com o governo, independentemente de seu estado de origem, da posição dos partidos de seus respectivos governadores e do tipo de matéria em votação.”.

Desse modo, a agenda do governo federal pode se impor com mais facilidade sobre as agendas estaduais específicas, se esse conflito tiver sido resolvido com os partidos políticos da sua coligação (ARRETCHE, 2019). Essa centralidade dos partidos políticos foi mapeada também pela literatura norte-americana. As evidências empíricas deram razões para abandonar o argumento de que o Senado seria um espaço institucional de proteção natural dos interesses estaduais, em razão de sua composição (WESCHLER, 1954). No entanto, Kramer (2000, p. 279) identifica como os interesses estaduais são incluídos na esfera federal na dinâmica real dos partidos políticos nos EUA. A chave repousaria em uma cultura de intensa cooperação entre os níveis locais, estaduais e federais dos partidos políticos durante os períodos eleitorais. Essa cultura "promove relacionamentos e cria obrigações entre agentes de diferentes esferas governamentais". Kramer trata esse relacionamento como "cultural" porque ele não decorre do seu desenho organizacional: ele é profundamente descentralizado. Como notam Jenkins e Roscoe (2014), esses relacionamentos e obrigações somente podem ser estabelecidos porque a atividade partidária local e estadual de fato influencia o resultado eleitoral na esfera federal.

Nesse sentido, a conclusão é dupla a respeito do mecanismo político no federalismo brasileiro. A primeira é que, quando o presidente tem uma coalizão ampla e sólida, a defesa dos interesses estaduais pelo legislativo federal depende da influência que os diretórios estaduais têm na formulação de orientações para os deputados federais e senadores. A segunda é que, na ausência de uma coalizão sólida - como no caso do Governo Bolsonaro -, o presidente precisa negociar de forma pontual com o Congresso Nacional a provação de seus projetos, e, desse modo, os governadores perdem o limite partidário para o embate direto com o presidente da República, com finalidades eleitorais.

Na ausência dessa coalizão partidária, o federalismo brasileiro pode tomar o rumo "estadualista” e descentralizado denunciado por Abrucio et al. (1994). Quando o presidente abre mão, ou é incapaz, de exercer liderança sobre os partidos políticos, os governadores disputam esse protagonismo e, por esse motivo, têm capacidade de influência sobre a conduta de seu partido na Câmara dos Deputados e possivelmente com os representantes de seus Estados no Senado Federal. Esse fortalecimento dos executivos subnacionais na ausência de coordenação federal 
já havia sido notado por Maria Hermínia Tavares de Almeida (1995) na década de 1990 e ecoada por Gilberto Bercovici (2002) no início dos anos 2000.

É por esses motivos que a coalizão partidária com abrangência federativa é também um mecanismo político de controle do governo federal. Uma vez realizada a coalizão, os interesses estaduais terão espaço proporcional à força dos diretórios estaduais nos partidos da coalizão. A ausência de coalizão estimula a descoordenação de serviços públicos e incentiva a competição entre presidente e governadores, especialmente em casos com potencial benefício ou prejuízo eleitoral. Esse é um mecanismo que combate a tentativa do presidente da República de assumir a conduta oportunista descrita no início desta seção.

Além disso, os governadores podem judicializar com facilidade os conflitos federativos não resolvidos, por meio de um mecanismo judicial. Nesse caso, caberá ao Supremo Tribunal Federal decidir se há uma imposição ilegítima de um ente federativo sobre o outro e, com isso, evitar condutas ilegais ou federativamente oportunistas, mantendo o equilíbrio nas condições de competição entre os entes federativos.

Há quatro grandes caminhos, em termos processuais, pelos quais o grau de liberdade e autonomia dos Estados pode ser decidido pelo Supremo Tribunal Federal $^{9}$. O primeiro deles se dá por meio do controle concentrado de constitucionalidade de normas por violação das competências federativas. Nesse caso, a ação é ajuizada diretamente no Supremo Tribunal Federal para verificar se a norma federal ou estadual (em certos casos até municipal) feriu a divisão de competências federativas estabelecidas na Constituição Federal. O segundo caminho se dá por uma via recursal ampla, por meio de recurso extraordinário. O recurso é cabível quando tribunais de justiça realizam o controle de constitucionalidade de normas estaduais e municipais perante a respectiva Constituição estadual, desde que a decisão tenha gerado potencial violação reflexa aos termos da Constituição Federal. Além disso, o recurso também é cabível em casos em que houve decisão envolvendo conflitos federativos ou que tiver sido declarada incidentalmente a inconstitucionalidade de norma federal. A terceira via se dá pelo ajuizamento de ação cível originária para discutir conflitos entre a União e os Estados. Em último lugar, o Supremo Tribunal Federal tem competência para controlar a constitucionalidade de emendas constitucionais (mesmo em seu

9 Essa lista de competência está definida no art. 102, I, $a$ e $f$, III, $b$ e $c$, bem como no art. 60 , $\$ 4^{\circ}$, da Constituição Federal. 
processo legislativo), caso considere que seu conteúdo viole gravemente, entre outras cláusulas pétreas, "a forma federativa”.

Essa amplitude de vias processuais abrangentes permite que diferentes atores institucionais levem os conflitos federativos, sob diferentes perspectivas e fundamentos, ao Supremo Tribunal Federal. Desse modo, essa amplitude de competências se constitui em um mecanismo adicional de proteção ao federalismo brasileiro aos Estados diante de ímpetos tanto autoritários quanto populistas por parte do governo federal. O modo como o Tribunal atuou com relação aos demais mecanismos de proteção federativa é abordado na seção seguinte.

\section{O sistema federativo responde ao Governo Bolsonaro}

Durante a pandemia de Covid-19, o Governo Bolsonaro tentou ser oportunista no campo federativo de duas maneiras principais. ${ }^{10}$ A primeira delas consistiu em impor a retomada precoce das atividades econômicas, em detrimento das políticas estaduais de isolamento social. A segunda consiste em reter a transferência de verbas federais aos Estados opositores que se tornaram inadimplentes durante a pandemia.

A tentativa de relaxamento das medidas de isolamento social é multifacetada. Sem o apoio do Congresso Nacional, o Governo Bolsonaro tentou alcançar esse resultado pela combinação de poderes legislativos presidenciais, administrativos e parainstitucionais. Sob o aspecto legislativo, editou a Medida Provisória 926/2020 para se conceder o poder de regular a atividade econômica durante a pandemia por decreto e, em seguida, editou os Decretos 10.282/2020 e 10.292/2020 para eximir uma série de atividades econômicas das políticas estaduais de isolamento social, como cabelereiros, lotéricas e academias de ginástica.

Sob o aspecto da ação administrativa, lançou a campanha publicitária "O Brasil não pode parar" para veicular a ideia de que as medidas de proteção à vida não poderiam ser implantadas às custas da atividade econômica (CNN BRASIL, 2020). Sob o aspecto da omissão administrativa, a rotação de pessoal no Ministério da Saúde e a nomeação de pessoas sem experiência para o cargo resultou em ampla subutilização do orçamento para combate à pandemia.

\footnotetext{
10 Para uma lista detalhada das medidas com impacto federativo durante o Governo Bolsonaro, cf. Abrucio et al., 2020. Os aspectos normativos da atuação de Bolsonaro durante a pandemia foram tratados em Conci (2020, p. 225-242).
} 
Em julho de 2020, aproximadamente 65\% dos recursos disponíveis a esse fim não tinham sido utilizados (CONSELHO NACIONAL DE SAÚDE, 2020). Na dimensão parainstitucional, publicou diversas mensagens contra o isolamento social e a favor do tratamento com hidroxocloroquina. Há, também, índices expressivamente mais altos de contaminação da população nos municípios em que o presidente tem mais apoio (GARCIA, 2020).

Entre essas medidas, o Supremo Tribunal Federal exerceu controle apenas sobre as ações do governo federal na dimensão legislativa e de ação administrativa. ${ }^{11}$ Apenas a medida provisória e os decretos foram declarados inconstitucionais com fundamento no equilíbrio federativo. Na Ação Direta de Inconstitucionalidade (ADI) $6.431^{12}$, o Tribunal reconheceu que a referida medida provisória não poderia servir para afastar a competência de Estados e Municípios no combate da pandemia. Já no julgamento da Arguição de Descumprimento de Preceito Fundamental (ADPF) $672^{13}$, o Supremo declarou que o presidente não poderia utilizar seus poderes administrativos e legislativos para interferir diretamente, anulando de maneira unilateral medidas como "imposição de distanciamento/isolamento social, quarentena, suspensão das atividades de ensino, restrições de comércio, atividades culturais e à circulação de pessoas, entre outros". À União ficou reservado o papel de edição de normas gerais para regular as medidas restritivas, sem poder modificar diretamente as medidas estaduais.

Nesse sentido, o Supremo Tribunal Federal tutelou parcialmente o oportunismo federativo, porque controlou apenas a sua dimensão mais visível de desmonte das políticas de distanciamento social. As omissões administrativas e a atividade parainstitucional não foram controladas. Mesmo assim, frustrada a dimensão mais robusta desse oportunismo concentrador, o Governo Bolsonaro capitalizou o evento em sua dimensão evasiva. Deu diversas entrevistas afirmando que o Supremo Tribunal Federal o impediu de combater a pandemia, que essa era uma responsabilidade exclusiva dos governadores e que estaria "de mãos atadas" (VIEIRA; GLEZER; BARBOSA, 2020). Sob uma iminência de segunda onda da

\footnotetext{
${ }^{11}$ A decisão tomada nas ADPFs 668 e 669 (STF, ADPF 668 MC, Decisão Monocrática, Rel. Min. Roberto Barroso, j. 31 mar. 2020; e STF, ADPF 669 MC, Decisão Monocrática, Rel. Min. Roberto Barroso, j. 31 mar. 2020) declarou a inconstitucionalidade da campanha publicitária do Governo Bolsonaro, mas sem qualquer referência à dimensão federativa.

${ }^{12}$ STF, ADI 6341 MC-Ref, Tribunal Pleno, Rel. Min. Marco Aurélio, Rel. p/acórdão Min. Edson Fachin, j. 15 abr. 2020.

${ }^{13}$ STF, ADPF 672 MC-Ref, Tribunal Pleno, Rel. Min. Alexandre de Moraes,13 out. 2020.
} 
pandemia, manteve a estratégia populista e evasiva. Esse tipo de oportunismo eleitoral não tem sofrido nenhum controle pelo Judiciário.

A autonomia dos Estados também foi atacada por ameaças de retenção das transferências constitucionais de verbas federais. O contexto da pandemia prejudicou, de maneira excepcional, a capacidade financeira dos Estados de pagarem suas dívidas, o que em tese permitiria à União reter os valores da dívida diretamente das transferências constitucionais. Apesar de a literalidade do texto constitucional autorizar esse tipo de medida, o Supremo Tribunal Federal estabeleceu uma série de restrições a atitudes dessa natureza que pudessem fragilizar de maneira desproporcional a autonomia estadual.

Esse é um tipo de conflito que chega ao Supremo Tribunal Federal por meio de ações cíveis originárias. Levantamento empírico recente de Dantas (2020) revela que, nesses casos de conflito fiscal de ordem federativa, o STF tende a proteger o interesse dos Estados em detrimento da União. Ao levantar dados específicos sobre os poderes da União de reter o repasse de verbas federais, foi possível verificar a continuidade dessa tendência, especialmente no período de pandemia. ${ }^{14}$

Mesmo antes da pandemia, o Supremo Tribunal Federal já havia decidido que a transferência de verbas constitucionais obrigatórias não poderia ser retida, mesmo em caso de dívida, caso tal retenção inviabilizasse a prestação de serviços públicos essenciais. Além disso, o Tribunal posiciona-se historicamente no sentido de que, quando houver dívida e for possível manter os serviços públicos essenciais, o procedimento de retenção somente pode ser realizado após o processo de tomada de conta especial, com garantia do devido processo legal e eventual apuração de responsabilidade dos gestores anteriores. ${ }^{15}$ Ademais, há casos em que

\footnotetext{
${ }^{14}$ Os dados foram obtidos a partir de pesquisa na busca avançada de jurisprudência do portal do STF, a partir das palavras-chave "art. 160 (em norma) e ACO (em classe)", incluindo apenas acórdãos; e ACO (em classe); "continuidade repasse" e "repasse estados dívida e ACO", com enfoque em decisões monocráticas. A primeira busca retornou 15 resultados, dos quais 6 se mostraram pertinentes. O restante deles não tratava diretamente da destinação de recursos e de eventuais sanções relacionadas a repasses. A segunda retornou 23 resultados, todos pertinentes. Por fim, a última retornou 5 resultados, todos impertinentes. A pesquisa foi complementada por uma busca de segurança nas notícias STF, a partir do termo "dívida estado". Agradeço à pesquisadora Ana Laura Pereira Barbosa pelo auxílio na coleta e no tratamento dos dados.

15 STF, ACO 1139, Rel. Min. Rosa Weber, j. 29 jun. 2018; STF, ACO 1803 MC, Tribunal Pleno, Rel. Min. Ricardo Lewandowski, j. 21 ago. 2017; STF, ACO 1357, Tribunal Pleno, Rel. Min. Ricardo Lewandowski, j. 1 set. 2017; STF, ACO 2733 MC, Tribunal Pleno, Rel. Min. Ricardo Lewandowski, j. 27 out. 2017; STF, ACO 1410, Primeira Turma, Rel. Min. Luiz Fux, j. 24 nov. 2015; STF, ACO 2785 MC, Tribunal Pleno, Rel. Min. Ricardo Lewandowski, j. 20 out. 2017 ; STF, ACO 1724, Tribunal Pleno, Rel. Min. Dias Toffoli, j. 3 mar. 2016; STF, ACO 2071, Tribunal Pleno, Rel. Min. Dias
} 
o STF impediu a União de utilizar esse poder fiscal como elemento abusivo de negociação, ao determinar que o refinanciamento de dívidas dos Estados com a União não pode ser condicionado à desistência de ações judiciais em curso. ${ }^{16}$ Por último, o Supremo Tribunal Federal determinou que a União deveria se abster de executar garantias - entre elas, o bloqueio de transferências - em decorrência do inadimplemento de parcelas de contratos de refinanciamento pelo Estado enquanto a questão estivesse sendo discutida judicialmente. ${ }^{17}$

Durante a pandemia, entre março e abril de 2020, 13 Estados ajuizaram ações cíveis originárias no Supremo Tribunal Federal para obter a suspensão das parcelas de dívidas por até 180 dias, sem que isso impeça a obtenção de novos empréstimos com a União. O STF acolheu a pretensão dos Estados, cujas ações somente foram extintas por perda de objeto quando o Congresso Nacional aprovou a Lei Complementar 173, de maio de 2020, garantindo esse direito a todos os Estados. ${ }^{18}$

Esses dados ajudam a corroborar a fragilidade do consenso acadêmico de que o Supremo Tribunal Federal tende a favorecer a União em detrimento dos Estados. Em levantamento empírico sobre conflito federativo, Glezer, Barbosa

Toffoli, j. 3 mar. 2016; STF, ACO 1870, Tribunal Pleno, Rel. Min. Dias Toffoli, j. 1 jul. 2016; STF, ACO 2805 MC, Rel. Min. Edson Fachin, j. 31 mar. 2016; STF, ACO 2591, Tribunal Pleno, Rel. Min. Dias Toffoli, j. 18 nov. 2016; STF, ACO 2968 MC, Primeira Turma, Rel. Min. Rosa Weber, j. 4 nov. 2020; STF, ACO 1120, Tribunal Pleno, Rel. Min. Ricardo Lewandowski, j. 30 jun. 2017; STF, ACO 2235, Primeira Turma, Rel. Min. Roberto Barroso, j. 28 set. 2018; STF, ACO 2811, Tribunal Pleno, Rel. Min. Dias Toffoli, j. 25 ago. 2017; STF, ACO 2803, Tribunal Pleno, Rel. Min. Dias Toffoli, j. 29 set. 2017; STF, ACO 2823, Tribunal Pleno, Rel. Min. Dias Toffoli, j. 7 nov. 2017; STF, ACO 2075, Tribunal Pleno, Rel. Min. Dias Toffoli, j. 27 abr. 2018; STF, ACO 3088 MC, Primeira Turma, Rel. Alexandre de Moraes, j. 1 mar. 2018 ; STF, ACO 3091 TA, Rel. Min. Marco Aurélio, j. 2 fev. 2018; STF, ACO 3096 TP, Tribunal Pleno, Rel. Min. Nunes Marques, processo em andamento; STF, ACO 3097 TP, Tribunal Pleno, Rel. Min. Rosa Weber. j. 21 set. 2020; STF, ACO 3147 MC, Tribunal Pleno, Rel. Min. Gilmar Mendes, j. 31 maio 2019 e STF, ACO 3163 MC, Rel. Min. Ricardo Lewandowski, j. 23 ago. 2018.

16 STF, ACO 3089 TP, Tribunal Pleno, Rel. Min. Ricardo Lewandowski. Processo em andamento e STF, ACO 3085 TA, Rel. Min. Roberto Barroso, j. 14 fev. 2018.

17 STF, ACO 3286, Tribunal Pleno, Rel. Min. Gilmar Mendes, j. 24 maio 2021; STF, ACO 3280, Rel. Min. Celso de Mello, j. 30 jul. 2019; STF, ACO 3285, Rel. Min. Alexandre de Moraes, j. 1 set. 2020 e STF, ACO 3215, Rel. Min. Nunes Marques, j. 22 jul. 2019.

18 STF, ACO 3363, Rel. Min. Alexandre de Moraes, j. 22 mar. 2020; STF, ACO 3365, Rel. Min. Alexandre de Moraes, j. 2 jun. 2020; STF, ACO 3371, Rel. Min. Alexandre de Moraes, j. 2 jun. 2020; STF, ACO 3372, Rel. Min. Alexandre de Moraes, j. 1 jun. 2020; STF, ACO 3373, Rel. Min. Alexandre de Moraes, j. 23 mar. 2021; STF, ACO 3368, Rel. Min. Alexandre de Moraes, j. 5 jun. 2020; STF, ACO 3369, Rel. Min. Alexandre de Moraes, j. 4 jun. 2020; STF, ACO 3370, Rel. Min. Alexandre de Moraes, j. 2 jun. 2020; STF, ACO 3374, Rel. Min. Alexandre de Moraes, j. 2 jun. 2020; STF, ACO 3377, Rel. Min. Alexandre de Moraes, j. jun. 2020; STF, ACO 3262, Rel. Min. Gilmar Mendes, j. 24 maio 2021 ; STF, ACO 3376, Rel. Min. Alexandre de Moraes, j. 1 jun. 2020 e STF, ACO 3375, Rel. Min. Alexandre de Moraes, j. 1 jun. 2020. 
e Cadedo (2021) argumentam que a ideia de que o Tribunal tende a favorecer a União é um mito que decorre de um viés problemático da maioria das pesquisas realizadas sobre o tema. A presente pesquisa serve para expandir essa conclusão. É possível dizer mais do que "o STF não tende a favorecer a União". É possível afirmar que o STF preserva a autonomia fiscal dos Estados perante a ação oportunista do governo federal. É possível dizer ainda que, perante um oportunismo populista materializado em normas jurídicas ou atos administrativos, o Supremo Tribunal Federal também exerceu um papel protetivo aos Estados durante a pandemia. Porém, os Estados permanecem vulneráveis à atuação populista realizada por omissões administrativas ou atos parainstitucionais. Essa é uma conclusão que reforça aquela de que o Supremo Tribunal Federal se mostra mais disposto a realizar controles que reforçam as exigências de consensualidade do sistema político, mantendo um equilíbrio competitivo entre os entes federativos.

\section{Conclusão}

O diagnóstico do federalismo como uma salvaguarda da democracia não é novo na literatura e remonta aos federalistas. Esta pesquisa, contudo, se junta às pesquisas recentes que avaliam a robustez dessa proteção, a partir do desenho institucional específico adotado pelo País. O alto grau de conflito federativo durante o Governo Bolsonaro fornece condições ricas de análise.

$\mathrm{O}$ arranjo federativo criou amplas dificuldades para que o Governo Bolsonaro implementasse ações oportunistas concentradoras, mas não evitou que ele mobilizasse e estimulasse o antagonismo com governadores, para alimentar seu populismo e projetar-se eleitoralmente. A pandemia de Covid-19 ilustra esse processo: sem conseguir interferir na política adotada pelos Estados e Municípios no combate à Covid-19, restou ao Governo Bolsonaro seguir antagonizando com os governadores e atribuindo a eles a responsabilidade exclusiva pela gestão das crises econômica e de saúde pública. Mesmo assim, o sistema federativo brasileiro deu condições estruturais para que os governadores reagissem no campo político.

Esse resultado indica que o desenho institucional federativo brasileiro dispõe de mecanismos estruturais, judiciais e políticos de oposição a condutas oportunistas. Eles operam conjuntamente para prevenir conflito em certas dimensões e para reagir ao conflito em outras dimensões. As ferramentas preventivas funcionam como salvaguardas contra interferências, por limitar o 
comportamento dos atores políticos e, com isso, evitar o risco de arbitrariedades ou retaliações a Estados. Já as ferramentas reativas podem ter caráter político ou judicial. Elas regulam eventuais conflitos, de modo a corrigir ou tornar custosa a realização de eventual abuso.

O fato de o Governo Bolsonaro não estabelecer uma sólida base partidária, em um sistema profundamente consensual como o brasileiro, tem implicações robustas para os conflitos federativos. De um lado, a ausência dessa coalizão limitou as condições do Governo Bolsonaro de exercer condutas oportunistas concentradores de poder. Sem maiorias parlamentares, não tem condição de interferir ou flexibilizar um sistema que concede altos graus de autonomia burocrática e financeira dos Estados. Além disso, a ausência de coalizão desestruturou a relação do presidente com os governadores, que não têm os limites partidários para o conflito com a União. Sendo assim, os governadores não têm custos de autonomia nem políticos por antagonizar o presidente da República. De outro lado, a ausência de coalizão partidária permitiu que o presidente pudesse explorar amplamente condutas oportunistas evasivas, visando maximizar o seu benefício eleitoral. Com essa conduta, o Governo Bolsonaro diminuiu os custos e criou incentivos para governadores se engajarem em conflito aberto e constante com o governo federal.

Esses resultados apontam para uma conclusão interessante. Na ciência política brasileira há uma espécie de disputa narrativa sobre a natureza do nosso federalismo. Fernando Abrúcio (1994) representa a tese de que o nosso sistema tem um amplo grau de pulverização de poderes, como uma espécie federalismo estadualista. Nessa narrativa o presidente pode ser constantemente pressionado por governadores, capazes de desestabilizar a implementação da agenda federal. Marta Arretche (2010), por sua vez, defende que as relações federativas são subordinadas às relações partidárias estabelecidas no nível federal. Nesse sentido, os governadores usufruem de uma razoável autonomia, mas têm poucas condições de interferir ou competir com a formulação de políticas federais. A presente pesquisa indica que essa disputa narrativa se dá em termos equivocados, pois há uma grande condição que modifica se o federalismo opera com governadores protagonistas ou coadjuvantes do sistema política: a existência ou inexistência, na prática, de uma coalizão partidária ampla e sólida em torno do presidente da República. A presença dessa coalizão limita de início os conflitos federativos por meio das negociações partidárias. 
De modo geral, o federalismo oscila entre uma prevenção silenciosa e uma reação estridente. Em momentos de prevenção silenciosa, o nosso federalismo pode ser considerado como inútil e, nos momentos de reação estridente, pode ser considerado disfuncional. Porém isso parece ser o fruto de uma compreensão inadequada de sua natureza. A Constituição e o Supremo Tribunal Federal estabelecem as condições de autonomia para essa prevenção silenciosa, bem como as condições de competição para uma reação estridente quando o presidente abaixa os custos e cria incentivos para a competição federativa, por meio de condutas oportunistas. Algo que se torna mais claro quando o federalismo passa a ser estudado menos a partir das definições de competências e mais pela investigação de sua finalidade.

\section{Referências}

ABRUCIO, Fernando Luiz. Os barões da federação. Lua Nova: Revista de Cultura e Política, São Paulo, n. 33, p. 165-183, 1994. Disponível em: https://www.scielo. $\mathrm{br} / \mathrm{j} / \mathrm{ln} / \mathrm{a} / \mathrm{KW}$ TCLTZW86HPNLZVGdrztD/?format=pdf\&lang=pt. Acesso em: 24 nov. 2021.

ABRUCIO, Fernando et al. Combate à COVID-19 sob o federalismo bolsonarista: um caso de descoordenação intergovernamental. Revista de Administração Pública, v. 54, n. 4, p. 663-677, 2020. Disponível em: https://www.scielo.br/j/ $\mathrm{rap} / \mathrm{a} / \mathrm{bpdbc9zSGCKZK55L3ChjVqJ/?format=pdf \& lang=pt.} \mathrm{Acesso} \mathrm{em:} 24$ nov. 2021.

ALMEIDA, Maria Hermínia Tavares de. Federalismo e políticas sociais. Revista Brasileira de Ciências Sociais, v. 10, n. 28, p. 88-108, 1995. Disponível em: http://www.anpocs.com/images/stories/RBCS/28/rbcs28_08.pdf. Acesso em: 24 nov. 2021.

ARRETCHE, Marta. Federalismo e igualdade territorial: uma contradição em termos? Dados, v. 53, n. 3, p. 587-620, 2010. Disponível em: https://www.scielo. br/j/dados/a/Lrm7KQHYssvHZk6GmRrrnfF/?format=pdf\&lang=pt. Acesso em: 24 nov. 2021.

ARRETCHE, Marta. Transferências fiscais no Brasil. In: MENEZES FILHO, Naercio; SOUZA, André Portela (org.). A Carta: para entender a Constituição brasileira. São Paulo: Todavia, 2019. p. 53-82. 
ARRETCHE, Marta Arretche; SCHLEGEL, Rogério. Os estados nas federações: Tendências gerais e o caso brasileiro. Banco Interamericanos de Desenvolvimento, 2014.

BAKER, Lynn A. Putting the Safeguards Back into the Political Safeguards of Federalism. Villanova Law Review, Vol. 46, no 951, 2001.

BARBOSA, Marina. Governador do ES alfineta Bolsonaro: Ele fica com 70\% da arrecadação. Correio Braziliense, 11 fev. 2020. Disponível em: https://www.correiobraziliense.com.br/app/noticia/economia/2020/02/11/ internas_economia,827282/governador-do-es-alfineta-bolsonaro-ele-fica-com70-da-arrecadacao.shtml. Acesso em: 10 nov. 2020.

BARBOSA, Marina; FERNANDES, Augusto; SOARES, Ingrid. Bolsonaro faz apelo a empresários para "jogarem pesado" contra governadores. Correio Braziliense, 15 maio 2020. Disponível em: https://www.correiobraziliense. com.br/app/noticia/politica/2020/05/15/interna_politica,855008/bolsonarofaz-apelo-a-empresarios-para-jogarem-pesado-contra-governa.shtml. Acesso em: 10 nov. 2020.

BARBOSA, Marina; SOARES, Ingrid. Bolsonaro diz que zera imposto em combustíveis se governadores zerarem ICMS. Correio Braziliense, 5 fev. 2020. Disponível em: https://www.correiobraziliense.com.br/app/noticia/ economia/2020/02/05/internas_economia,825859/bolsonaro-zera-imposto-emcombustiveis-se-governadores-zerarem-icms.shtml. Acesso em: 10 nov. 2020.

BBC NEWS. Em rede nacional, Bolsonaro critica fechamento de escolas e comércio e compara coronavírus a 'resfriadinho' BBC News Brasil, 24 mar. 2020. Disponível em: https://www.bbc.com/portuguese/brasil-52028945. Acesso em: 14 nov. 2020.

BÉDARD-RUBIN, Jean-Christophe. Senate reform and the political safeguards of Canadian Federalism in Québec. Constitutional Forum, v. 28, n. 1, p. 19-28, 2019. Disponível em: https://journals.library.ualberta.ca/constitutional_forum/index. php/constitutional_forum/article/view/29375/21374. Acesso em: 24 nov. 2021.

BEDNAR, Jenna. Federalism as a public good. Constitutional Political Economy, v. 16, n. 2, p. 189-205, 2005. Disponível em: https://deepblue.lib. umich.edu/bitstream/handle/2027.42/44798/10602_2005_Article_2235. pdf? sequence=1\&isAllowed=y. Acesso em: 24 nov. 2021 . 
BEDNAR, Jenna. The robust federation: principles of design. 1. ed. Cambridge; New York: Cambridge University Press, 2008.

BERCOVICI, Gilberto. A descentralização de políticas sociais e o federalismo cooperativo brasileiro. Revista de Direito Sanitário, v. 3, n. 1, p. 13-28, 2002. Disponível em: https://www.revistas.usp.br/rdisan/article/view/81291/84931. Acesso em: 24 nov. 2021.

BERTONI, Estevão. Como Bolsonaro desautoriza seus ministros da Saúde. Nexo, 21 out. 2020. Disponível em: https://www.nexojornal.com.br/ expresso/2020/10/21/Como-Bolsonaro-desautoriza-seus-ministros-daSa\%C3\%BAde. Acesso em: 24 nov. 2021.

BULMAN-POZEN, Jessica. Federalism as a safeguard of the separation of powers. Columbia Law Review, v. 112, p. 459-506, 2012. Disponível em: https://scholarship.law.columbia.edu/cgi/viewcontent. cgi ?article=2733\&context=faculty_scholarship. Acesso em: 24 nov. 2021 .

BULMAN-POZEN, Jessica; GERKEN, Heather K. Uncooperative federalism. The Yale Law Journal, v. 118, n. 7, p. 1256-1583, may 2009. Disponível em: https://www. yalelawjournal.org/article/uncooperative-federalism. Acesso em: 24 nov. 2021.

BRONZATTO, Thiago. Como o governo Bolsonaro monitora o 'alinhamento' com cada governador. VEJA, 21 abr. 2020, Disponível em: https://veja.abril.com. br/politica/otimo-bom-neutro-ruim-e-muito-ruim/. Acesso em: 10 nov. 2020.

CANCIAN, Natália. Governo Bolsonaro tem estoque parado de 4 milhões de comprimidos de cloroquina. Folha de São Paulo, 23 jul. 2020. Disponível em: https://www1.folha.uol.com.br/cotidiano/2020/07/governo-bolsonaro-temestoque-parado-de-4-milhoes-de-comprimidos-de-cloroquina.shtml. Acesso em: 13 nov. 2020.

CHEIBUB, José Antonio; FIGUEIREDO, Argelina; LIMONGI, Fernando. Partidos políticos e governadores como determinantes do comportamento legislativo na Câmara dos Deputados, 1988-2006. Dados-Revista de Ciências Sociais, v. 52, n. 2, p. 263-299, 2009. Disponível em: https://www.scielo.br/j/dados/a/ DXSzSH9PCC66Sbfpzb4tTwy/?format=pdf\&lang=pt. Acesso em: 24 nov. 2021.

CNN Brasil. Governo lança campanha "Brasil Não Pode Parar" contra medidas de isolamento. CNN Brasil, 27 mar. 2020. Disponível em: https://www.cnnbrasil. com.br/politica/2020/03/27/governo-lanca-campanha-brasil-nao-pode-pararcontra-medidas-de-isolamento. Acesso em: 15 nov. 2020. 
CONCI, Luiz Guilherme Arcaro. Impacto da pandemia da Covid-19 na federação brasileira: descentralizando a disfuncionalidade. Opinión Jurídica, v. 19, n. 40, Edición especial 2020, p. 225-242, 2020. Disponível em: http://www.scielo.org. co/pdf/ojum/v19nspe40/2248-4078-ojum-19-spe40-225.pdf. Acesso em: 24 nov. 2021.

CONSELHO NACIONAL DE SAÚDE. 66\% dos recursos destinados à Saúde para enfrentar a pandemia ainda estão parados, mostra boletim do CNS. Conselho Nacional de Saúde, 19 jun. 2020. Disponível em: https://conselho.saude.gov. br/ultimas-noticias-cns/1230-66-dos-recursos-destinados-a-saude-paraenfrentar-a-pandemia-ainda-estao-parados-mostra-boletim-do-cns. Acesso em: 15 nov. 2020.

CORREIO DO POVO. Governador da Bahia diz que vídeo publicado por Flávio Bolsonaro não é de Adriano. Correio do Povo, 20 fev. 2020. Disponível em: https://www.correiodopovo.com.br/not\%C3\%ADcias/pol\%C3\%ADtica/ governador-da-bahia-diz-que-v\%C3\%ADdeo-publicado-por-fl\%C3\%A1viobolsonaro-n\%C3\%A3o-\%C3\%A9-de-adriano-1.400686. Acesso em: 10 nov. 2020.

DANTAS, Dimitrius. Doria chama Bolsonaro de "negacionista" e diz que SP poderá vacinar pessoas de outros estados, Extra Online, 22 out. 2020. Disponível em: https:/extra.globo.com/noticias/brasil/doria-chama-bolsonaro-de-negacionistadiz-que-sp-podera-vacinar-pessoas-de-outros-estados-24706114.html. Acesso em: 23 out. 2020.

ESTADÃO CONTEÚDO. Governo de SP cobra governo Bolsonaro para ter mais verba para vacina chinesa, Estado de Minas, 15 out. 2020a. Disponível em: https:// www.em.com.br/app/noticia/nacional/2020/10/15/interna_nacional,1194987/ governo-de-sp-cobra-governo-bolsonaro-para-ter-mais-verba-para-vacina. shtml. Acesso em: 10 nov. 2020.

ESTADÃO CONTEÚDO. Agência do Estado. Bolsonaro visita obra em São Vicente com adversários de Doria. R7 Brasil, 23 ago. 2020b. Disponível em: https://noticias.r7.com/brasil/bolsonaro-visita-obra-em-sao-vicente-comadversarios-de-doria-07082020. Acesso em: 10 nov. 2020.

FARIAS, Victor. Bolsonaro inaugura obra no Maranhão sem Flávio Dino e elogia parlamentares do estado. O Globo, 29 out. 2020. Disponível em: https:// oglobo.globo.com/brasil/bolsonaro-inaugura-obra-no-maranhao-sem-flaviodino-elogia-parlamentares-do-estado-1-24718563. Acesso em: 10 nov. 2020. 
G1 MA. Bolsonaro critica lockdown e compara Maranhão à Venezuela; Governador Flávio Dino reage. G1 Maranhão, 10 maio 2020. Disponível em: https://g1.globo.com/ma/maranhao/noticia/2020/05/10/bolsonaro-criticalockdown-e-compara-maranhao-a-venezuela-governador-flavio-dino-reage. ghtml. Acesso em: 10 nov. 2020.

G1 (Brasília). Em carta, governadores de 20 estados manifestam apoio a Maia e Alcolumbre, G1, 19 abr. 2020. Disponível em: https://g1.globo.com/politica/ noticia/2020/04/19/em-carta-governadores-de-20-estados-manisfestam-apoioa-maia-e-alcolumbre.ghtml. Acesso em: 13 nov. 2020.

GARCIA, Diego. "Efeito Bolsonaro" sobre alta nos casos de coronavírus surpreende pesquisadores. Folha de São Paulo, 12 out. 2020. Disponível em: https://www1. folha.uol.com.br/mercado/2020/10/efeito-bolsonaro-sobre-alta-nos-casos-decoronavirus-surpreende-pesquisadores.shtml. Acesso em: 15 nov. 2020.

GAVIOLI, Allan. Mais uma que Jair Bolsonaro ganha: presidente se pronuncia após interrupção de testes da CoronaVac. Infomoney, 10 nov. 2020. Disponível em: https://www.infomoney.com.br/politica/mais-uma-que-jair-bolsonaroganha-presidente-se-pronuncia-apos-interrupcao-de-testes-da-coronavac/. Acesso em: 14 dez. 2020.

GINSBURG, Tom; VERSTEEG, Mila. Binding the unbound executive: checks and balances in times of pandemic. 2020. (Virginia Public Law and Legal Theory Research Paper, N²020-52; Universtiy of Chicago, Public Law Working Paper, $\mathrm{N}^{\circ}$ 747). Disponível em: https://papers.ssrn.com/sol3/Delivery. cfm/SSRN_ID3661997_code243779.pdf?abstractid=3608974\& $\mathrm{mirid}=1$. Acesso em: 24 nov. 2021.

GLEZER, Rubens; BARBOSA, Ana Laura. P.; CADEDO, Matheus. O mito da jurisprudência federalista concentradora do STF: uma nova proposta de análise dos conflitos federativos. Revista Brasileira de Estudos Constitucionais RBEC, v. 15, n. 47, jan./jun. 2021.

GREENE, Francis R. Madison's view of federalism in The Federalist. Publius: The Journal of Federalism, v. 24, n. 1, p. 47-62, winter 1994. 
GRILLO, Marco. Bolsonaro diz que função do governo na pandemia de coronavírus é apenas repassar bilhões aos estados e que alguns governadores "ainda desviam" recursos, O Globo, 8 jun. 2020. Disponível em: https://oglobo. globo.com/brasil/bolsonaro-diz-que-funcao-do-governo-na-pandemia-decoronavirus-apenas-repassar-bilhoes-aos-estados-que-alguns-governadoresainda-desviam-recursos-24468329. Acesso em: 10 nov. 2020.

JENKINS, Shannon; ROSCOE, Douglas D. Parties as the political safeguards of federalism: the impact of local political party activity on national elections. Publius: The Journal of Federalism, v. 44, n. 3, p. 519-540, 2014.

KAMENA JUNIOR, Theodore Henry. Populism and federalism: the interplay of direct democracy and federal institutions in Australia, Canada, Switzerland and the United States. Calgary: University of Calgary, 2001. Disponível em: https://prism.ucalgary.ca/bitstream/handle/1880/41090/64818Kamena. pdf? sequence=1\&isAllowed=y. Acesso em: 25 nov. 2021 .

KYLE, Jordan; MOUNK, Yascha, The populist harm to democracy: an empirical assessment. Tony Blair Institute for Global Change, $26 \mathrm{dez}$. 2018. Disponível em: https://institute.global/policy/populist-harm-democracy-empiricalassessment. Acesso em: 25 nov. 2021.

KRAMER, Larry D. Putting the Politics Back into the Political Safeguards of Federalism. Columbia Law Review, v. 100, p. 279, 2000.

LANDAU, David; WISEMAN, Hannah J.; WISEMAN, Samuel R. Federalism for the Worst Case. Iowa Law Review, v. 105, p. 1187-1255, 2020. Disponível em: https://ilr.law.uiowa.edu/print/volume-105-issue-3/federalism-for-the-worstcase/. Acesso em: 12 nov. 2020.

LIMONGI, Fernando; CORTEZ, Rafael. As eleições de 2010 e o quadro partidário. Novos Estudos CEBRAP, São Paulo, v. 29, n. 88, p. 21-37, nov. 2010. Disponível em: http://novosestudos.com.br/wp-content/uploads/2017/03/03_LIMONGI_ NEC88_20a37.pdf.zip. Acesso em: 25 nov. 2021.

MAIA, Gustavo; TRINDADE, Naira. Bolsonaro defende que governadores e prefeitos paguem encargos trabalhistas por dias parados. O Globo, 27 mar. 2020. Disponível em: https://oglobo.globo.com/brasil/bolsonaro-defendeque-governadores-prefeitos-paguem-encargos-trabalhistas-por-diasparados-24332785. Acesso em: 10 nov. 2020. 
MADISON, James et al. The Federalist Papers. Oxford: Oxford University Press, 2008.

MARTELO, Alexandre. Ibaneis diz que é “irresponsável” forma como Bolsonaro propôs reduzir preço de combustível. G1 Distrito Federal, 11 fev. 2020. Disponível em: https://g1.globo.com/df/distrito-federal/noticia/2020/02/11/ ibaneis-diz-que-e-irresponsavel-forma-como-bolsonaro-propos-reduzir-precode-combustivel.ghtml. Acesso em: 10 nov. 2020.

MAZUI, Guilherme. Bolsonaro ri ao ouvir comentário sobre operação contra Witzel e dá parabéns à PF. G1, 26 maio 2020. Disponível em: https://g1.globo. $\mathrm{com} / \mathrm{politica} /$ noticia/2020/05/26/bolsonaro-ri-ao-ser-questionado-sobreoperacao-contra-witzel-e-da-parabens-a-pf.ghtml. Acesso em: 10 nov. 2020.

MILLHISER, Ian. Federalism in a time of autocracy. Yale Law \& Policy Review, v. 35, n. 2, p. 521-538, 2016. Disponível em: https://ylpr.yale.edu/sites/default/ files/YLPR/millhiser_produced.web_.pdf. Acesso em: 25 nov. 2021.

MOTTA, Anaís. Mandetta, Teich, Pazuello e Queiroga: os 4 ministros da Saúde da pandemia. UOL, São Paulo, 15 mar. 2021. Disponível em: https://noticias.uol. com.br/saude/ultimas-noticias/redacao/2021/03/15/mandetta-teich-pazuelloe-queiroga-os-4-ministros-da-saude-da-pandemia.htm?cmpid=copiaecola.

Acesso em: 10 ago. 2021.

MUDDE, Cas, Populism: an ideational approach. In: KALTWASSER, Cristóbal Rovira et al. (ed.). The Oxford handbook of populism. Oxford: Oxford University Press, 2017. p. 61-63

PORTO, Douglas. Anvisa interrompe estudos clínicos da Coronavac: Butantan alega surpresa. UOL, São Paulo, 9 nov. 2020. Disponível em: https://noticias. uol.com.br/saude/ultimas-noticias/redacao/2020/11/09/anvisa-determinainterrupcao-de-estudos-clinicos-sobre-coronavac.htm. Acesso em: 10 nov. 2020.

OBYDENKOVA, Anastassia; SWENDEN, Wilfried. Autocracy-Sustaining Versus Democratic Federalism: Explaining the Divergent Trajectories of Territorial Politics in Russia and Western Europe. In: Territory, Politics, Governance. v. 1, n. 1, pp. 86-112, 2013. 
PEREIRA, Felipe; MAZIEIRO, Guilherme. Morte que suspendeu pesquisas da CoronaVac foi suicídio de voluntário. UOL, São Paulo, 10 nov. 2020. Disponível em: https://noticias.uol.com.br/saude/ultimas-noticias/redacao/2020/11/10/ morte-que-suspendeu-teste-nao-tem-relacao-com-coronavac-nem-com-covid-19. htm. Acesso em: 10 nov. 2020.

PITOMBO, João Pedro. Governador do PT reivindica autoria de obra que será inaugurada por Bolsonaro: Novo aeroporto de Vitória da Conquista receberá presidente em evento na terça (23). Folha de São Paulo, 18 jul. 2019. Disponível em: https://www1.folha.uol.com.br/poder/2019/07/governadordo-pt-reivindica-autoria-de-obra-que-sera-inaugurada-por-bolsonaro.shtml. Acesso em: 10 nov. 2020.

ROCHA, Lucas. Vacinas da Covid-19 não têm relação com HIV e Aids: entenda. CNN Brasil, 25 out. 2021. Disponível em: https://www.cnnbrasil.com.br/saude/ vacinas-da-covid-19-nao-tem-relacao-com-hiv-e-aids-entenda/. Acesso em 25 out. 2021.

ROXO, Sérgio. Bolsonaro exclui governadores adversários de inaugurações. O Globo, 9 set. 2020. Disponível em: https://oglobo.globo.com/brasil/bolsonaroexclui-governadores-adversarios-de-inauguracoes-2462532. Acesso em: 10 nov. 2020.

SILVA, Cristian Jesus da. A importância do federalismo na dinâmica do presidencialismo de coalizão no Senado Federal. 2015. 69 f. Monografia (Pós-graduação lato sensu em Ciência Política) - Instituto Legislativo Brasileiro, Senado Federal, Brasília, 2015. Disponível em: https://www2.senado.leg.br/ bdsf/handle/id/516899. Acesso em: 13 nov. 2020.

SILVA, Virgílio Afonso. Federalismo e articulação de competências no Brasil. In: ETERS, B. Guy; PIERRE, Jon (org.). Administração pública: coletânea. São Paulo: UNESP; Brasília: ENAP, 2010, p. 549-570.

STARODUBTSEV, Andrey. Federalism and regional policy in contemporary Russia. 1. ed. Abingdon, Oxford; New York, NY: Routledge, 2017.

UOL. Bolsonaro faz piada homofóbica no MA: virei boiola, igual maranhense. UOL, São Paulo, 29 out. 2020. Disponível em: https://noticias.uol.com.br/politica/ ultimas-noticias/2020/10/29/bolsonaro-faz-piada-preconceituosa-no-ma-vireiboiola-igual-maranhense.htm. Acesso em: 10 nov. 2020. 
VIEIRA, Oscar Vilhena; GLEZER, Rubens; BARBOSA, Ana Laura P. Governando sem coalizão: um balanço sobre o primeiro ano do Governo Bolsonaro. In: BRANCO, Pedro H. v. B. C.; GOUVÊA, Carina B.; LAMENHA, Bruno (org.). Populismo, constitucionalismo populista, jurisdição populista e crise da democracia. Belo Horizonte: Ed. Letramento, 2020.

VILELA, Pedro Rafael. Bolsonaro recebeu apoio de 15 dos 27 governadores eleitos. Agência Brasil, 28 out. 2018. Disponível em: https://agenciabrasil. ebc.com.br/politica/noticia/2018-10/bolsonaro-recebeu-apoio-de-15-dos-27governadores-eleitos. Acesso em: 13 nov. 2020.

WESCHLER, Herbert. The political safeguards of federalism: the role of the States in the composition and selection of the National Government. Columbia Law Review, v. 54, n. 4, p. 543-560, 1954.

\section{Jurisprudência citada}

BRASIL. Supremo Tribunal Federal (Tribunal Pleno). Ação Cível Originária 1.120/RJ. Relator: Min. Ricardo Lewandowski, 30 de junho de 2017. Disponível em: http://portal.stf.jus.br/processos/detalhe. asp?incidente=2589959. Acesso em: 25 nov. 2021.

BRASIL. Supremo Tribunal Federal. Ação Cível Originária 1.139/SP. Relatora: Min. Rosa Weber, 29 de junho de 2018. Disponível em: http://portal.stf.jus.br/ processos/detalhe.asp?incidente $=2603838$. Acesso em: 25 nov. 2021 .

BRASIL. Supremo Tribunal Federal (Tribunal Pleno). Ação Cível Originária 1.357/RJ. Relator: Min. Ricardo Lewandowski, 1 set. 2017. Disponível em: http://portal.stf.jus.br/processos/detalhe.asp?incidente=2667436. Acesso em: 25 nov. 2021.

BRASIL. Supremo Tribunal Federal (Primeira Turma). Ação Cível Originária 1.410/MT. Relator: Min. Luiz Fux, 24 de novembro de 2015. Disponível em: http://portal.stf.jus.br/processos/detalhe.asp?incidente=2691216. Acesso em: 25 nov. 2021.

BRASIL. Supremo Tribunal Federal (Tribunal Pleno). Ação Cível Originária 1.724/PI. Relator: Min. Dias Toffoli, 3 de março de 2016. Disponível em: http:// portal.stf.jus.br/processos/detalhe.asp?incidente $=4017092$. Acesso em: 25 nov. 2021. 
BRASIL. Supremo Tribunal Federal (Tribunal Pleno). Ação Cível Originária 1.803/DF MC. Relator: Min. Ricardo Lewandowski, 21 de agosto de 2017. Disponível em: http://portal.stf.jus.br/processos/detalhe. asp?incidente $=4104175$. Acesso em: 25 nov. 2021.

BRASIL. Supremo Tribunal Federal (Tribunal Pleno). Ação Cível Originária 1.870/DF. Relator: Min. Dias Toffoli, 1 de julho de 2016. Disponível em: http:// portal.stf.jus.br/processos/detalhe.asp?incidente=4165921. Acesso em: 25 nov. 2021 .

BRASIL. Supremo Tribunal Federal (Tribunal Pleno). Ação Cível Originária 2.071/SC. Relator: Min. Dias Toffoli, 3 de março de 2016. Disponível em: http:// portal.stf.jus.br/processos/detalhe.asp?incidente $=4344938$. Acesso em: 25 nov. 2021 .

BRASIL. Supremo Tribunal Federal (Tribunal Pleno). Ação Cível Originária 2.075/PI. Relator: Min. Dias Toffoli, 27 de abril de 2018. Disponível em: http:// portal.stf.jus.br/processos/detalhe.asp?incidente $=4347564$. Acesso em: 25 nov. 2021 .

BRASIL. Supremo Tribunal Federal (Primeira Turma). Ação Cível Originária 2.235/PR. Relator: Min. Roberto Barroso, 28 de setembro de 2018. Disponível em: http://portal.stf.jus.br/processos/detalhe.asp?incidente=4467294. Acesso em: 25 nov. 2021.

BRASIL. Supremo Tribunal Federal (Tribunal Pleno). Ação Cível Originária 2.591/DF. Relator: Min. Dias Toffoli, 18 de novembro de 2016. Disponível em: http://portal.stf.jus.br/processos/detalhe. asp?incidente $=4694254$. Acesso em: 25 nov. 2021.

BRASIL. Supremo Tribunal Federal (Tribunal Pleno). Ação Cível Originária 2.733/AC MC. Relator: Min. Ricardo Lewandowski, j. 27 out. 2017. Disponível em: http://portal.stf.jus.br/processos/detalhe. asp?incidente=4826609. Acesso em: 25 nov. 2021.

BRASIL. Supremo Tribunal Federal (Tribunal Pleno). Ação Cível Originária 2.785/RN MC. Relator: Min. Ricardo Lewandowski, 20 de outubro de 2017. Disponível em: http://portal.stf.jus.br/processos/detalhe. asp?incidente $=4890407$. Acesso em: 25 nov. 2021.

BRASIL. Supremo Tribunal Federal (Tribunal Pleno). Ação Cível Originária 2.803/RN. Relator: Min. Dias Toffoli, 29 de setembro de 2017. Disponível em: http://portal.stf.jus.br/processos/detalhe.asp?incidente $=4911824$. Acesso em: 25 nov. 2021. 
BRASIL. Supremo Tribunal Federal. Ação Cível Originária 2.805/DF MC. Relator: Min. Edson Fachin, 31 de março de 2016. Disponível em: http://portal. stf.jus.br/processos/detalhe. asp?incidente $=4913628$. Acesso em: 25 nov. 2021 .

BRASIL. Supremo Tribunal Federal (Tribunal Pleno). Ação Cível Originária 2.811/AM. Relator: Min. Dias Toffoli, 25 de agosto de 2017. Disponível em: http://portal.stf.jus.br/processos/detalhe.asp?incidente $=4917593$. Acesso em: 25 nov. 2021.

BRASIL. Supremo Tribunal Federal (Tribunal Pleno). Ação Cível Originária 2.823/DF. Relator: Min. Dias Toffoli, 7 de novembro de 2017. Disponível em: http://portal.stf.jus.br/processos/detalhe.asp?incidente=4925600. Acesso em: 25 nov. 2021.

BRASIL. Supremo Tribunal Federal (Primeira Turma). Ação Cível Originária 2.968/DF MC. Relatora: Min. Rosa Weber, 4 de novembro de 2020. Disponível em: http://portal.stf.jus.br/processos/detalhe. asp?incidente $=5113895$. Acesso em: 25 nov. 2021.

BRASIL. Supremo Tribunal Federal. Ação Cível Originária 3.085/AL TA. Relator: Min. Roberto Barroso, 14 de fevereiro de 2018. Disponível em: http:// portal.stf.jus.br/processos/detalhe.asp?incidente $=5329910$. Acesso em: 25 nov. 2021.

BRASIL. Supremo Tribunal Federal (Primeira Turma). Ação Cível Originária 3.088/DF MC. Relator: Min. Alexandre de Moraes, 1 de março de 2018. Disponível em: http://portal.stf.jus.br/processos/detalhe.asp?incidente=5335083. Acesso em: 25 nov. 2021.

BRASIL. Supremo Tribunal Federal (Tribunal Pleno). Ação Cível Originária 3.089/DF TP. Relator: Min. Ricardo Lewandowski. Andamento processual disponível em: http://portal.stf.jus.br/processos/detalhe.asp?incidente=5335291. Acesso em: 25 nov. 2021. (sem julgamento até a presente data)

BRASIL. Supremo Tribunal Federal. Ação Cível Originária 3.091/DF TA. Relator: Min. Marco Aurélio, 2 de fevereiro de 2018. Disponível em: http://portal. stf.jus.br/processos/detalhe.asp?incidente=5335961. Acesso em: 25 nov. 2021.

BRASIL. Supremo Tribunal Federal (Tribunal Pleno). Ação Cível Originária 3.096/PE TP. Relator: Min. Nunes Marques. Andamento processual disponível em: http://portal.stf.jus.br/processos/detalhe.asp?incidente=5338987. Acesso em: 25 nov. 2021. (sem julgamento até a presente data) 
BRASIL. Supremo Tribunal Federal (Tribunal Pleno). Ação Cível Originária 3.097/PE TP. Relatora: Min. Rosa Weber. 21 de setembro de 2020. Disponível em: http://portal.stf.jus.br/processos/detalhe. asp?incidente $=5338989$. Acesso em: 25 nov. 2021.

BRASIL. Supremo Tribunal Federal (Tribunal Pleno). Ação Cível Originária 3.147/PE MC. Relator: Min. Gilmar Mendes, 31 de maio de 2019. Disponível em: http://portal.stf.jus.br/processos/detalhe.asp?incidente=5503961. Acesso em: 25 nov. 2021.

BRASIL. Supremo Tribunal Federal. Ação Cível Originária 3.163/DF MC. Relator: Min. Ricardo Lewandowski, 23 de agosto de 2018. Disponível em: http://portal. stf.jus.br/processos/detalhe. asp?incidente $=5529598$. Acesso em: 25 nov. 2021 .

BRASIL. Supremo Tribunal Federal. Ação Cível Originária 3.215/DF. Relator: Min. Nunes Marques, 22 de julho de 2019. Disponível em: http://portal.stf.jus. br/processos/detalhe. asp?incidente=5615705. Acesso em: 25 nov. 2021.

BRASIL. Supremo Tribunal Federal. Ação Cível Originária 3.262/GO. Relator: Min. Gilmar Mendes, 24 de maio de 2021. Disponível em: http://portal.stf.jus. br/processos $/$ detalhe.asp?incidente $=5695626$. Acesso em: 25 nov. 2021.

BRASIL. Supremo Tribunal Federal. Ação Cível Originária 3.280/DF. Relator: Min. Celso de Mello, 30 de julho de 2019. Disponível em: http://portal.stf.jus. br/processos/detalhe.asp?incidente=5729710. Acesso em: 25 nov. 2021.

BRASIL. Supremo Tribunal Federal. Ação Cível Originária 3.285/AP. Relator: Min. Alexandre de Moraes, 1 de setembro de 2020. Disponível em: http://portal. stf.jus.br/processos/detalhe.asp?incidente $=5733931$. Acesso em: 25 nov. 2021 .

BRASIL. Supremo Tribunal Federal (Tribunal Pleno). Ação Cível Originária 3.286/DF. Relator: Min. Gilmar Mendes, 24 de maio de 2021. Disponível em: http://portal.stf.jus.br/processos/detalhe.asp?incidente=5734554. Acesso em: 25 nov. 2021.

BRASIL. Supremo Tribunal Federal. Ação Cível Originária 3.363/SP. Relator: Min. Alexandre de Moraes, 22 de março de 2020. Disponível em: http://portal. stf.jus.br/processos/detalhe.asp?incidente $=5880014$. Acesso em: 25 nov. 2021 .

BRASIL. Supremo Tribunal Federal. Ação Cível Originária 3.365/BA. Relator: Min. Alexandre de Moraes, 2 de junho de 2020. Disponível em: http://portal. stf.jus.br/processos/detalhe.asp?incidente=5880757. Acesso em: 25 nov. 2021 . 
BRASIL. Supremo Tribunal Federal. Ação Cível Originária 3.368/PB. Relator: Min. Alexandre de Moraes, 5 de junho de 2020. Disponível em: http://portal. stf.jus.br/processos/detalhe.asp?incidente $=5882113$. Acesso em: 25 nov. 2021 .

BRASIL. Supremo Tribunal Federal. Ação Cível Originária 3.369/DF. Relator: Min. Alexandre de Moraes, 4 de junho de 2020. Disponível em: http://portal. stf.jus.br/processos/detalhe.asp?incidente $=5882452$. Acesso em: 25 nov. 2021 .

BRASIL. Supremo Tribunal Federal. Ação Cível Originária 3.370/SC. Relator: Min. Alexandre de Moraes, 2 de junho de 2020. Disponível em: http://portal. stf.jus.br/processos/detalhe.asp?incidente $=5882780$. Acesso em: 25 nov. 2021 .

BRASIL. Supremo Tribunal Federal. Ação Cível Originária 3.371/DF. Relator: Min. Alexandre de Moraes, 2 de junho de 2020. Disponível em: http://portal. stf.jus.br/processos/detalhe.asp?incidente $=5883176$. Acesso em: 25 nov. 2021 .

BRASIL. Supremo Tribunal Federal. Ação Cível Originária 3.372/DF. Relator: Min. Alexandre de Moraes, j. 1 jun. 2020. Disponível em: http://portal.stf.jus. br/processos/detalhe. asp?incidente $=5883177$. Acesso em: 25 nov. 2021 .

BRASIL. Supremo Tribunal Federal. Ação Cível Originária 3.373/PA. Relator: Min. Alexandre de Moraes, 23 de março de 2021. Disponível em: http://portal. stf.jus.br/processos/detalhe.asp?incidente $=5883707$. Acesso em: 25 nov. 2021 .

BRASIL. Supremo Tribunal Federal. Ação Cível Originária 3.374/AL. Relator: Min. Alexandre de Moraes, 2 de junho de 2020. Disponível em: http://portal. stf.jus.br/processos/detalhe.asp?incidente $=5883931$. Acesso em: 25 nov. 2021 .

BRASIL. Supremo Tribunal Federal. Ação Cível Originária 3.375/ES. Relator: Min. Alexandre de Moraes, 1 de junho de 2020. Disponível em: http://portal. stf.jus.br/processos/detalhe.asp?incidente $=5884108$. Acesso em: 25 nov. 2021 .

BRASIL. Supremo Tribunal Federal. Ação Cível Originária 3.376/AM. Relator: Min. Alexandre de Moraes, 1 de junho de 2020. Disponível em: http://portal. stf.jus.br/processos/detalhe.asp?incidente $=5885939$. Acesso em: 25 nov. 2021 .

BRASIL. Supremo Tribunal Federal. Ação Cível Originária 3.377/RO. Relator: Min. Alexandre de Moraes, 1 junho de 2020. Disponível em: http://portal.stf. jus.br/processos/detalhe.asp?incidente=5886115. Acesso em: 25 nov. 2021 . 
BRASIL. Supremo Tribunal Federal (Tribunal Pleno). Ação Direta de Inconstitucionalidade 6.431/DF. Relator: Min. Roberto Barroso, 21 de maio de 2020. Disponível em: http://portal.stf.jus.br/processos/detalhe. asp?incidente $=5915876$. Acesso em: 26 nov. 2021.

BRASIL. Supremo Tribunal Federal (Decisão Monocrática). Medida Cautelar na Arguição de Descumprimento de Preceito Fundamental 668/DF. Relator: Min. Roberto Barroso, 31 de março de 2020. Disponível em: http://portal.stf. jus.br/processos/downloadPeca.asp?id=15342798641\&ext=.pdf. Acesso em: 25 nov. 2021.

BRASIL. Supremo Tribunal Federal (Decisão Monocrática). Medida Cautelar na Arguição de Descumprimento de Preceito Fundamental 669/DF. Relator: Min. Roberto Barroso, 31 de março de 2020. Disponível em: http://portal.stf. jus.br/processos/downloadPeca.asp?id=15342798642\&ext=.pdf. Acesso em: 25 nov. 2021.

BRASIL. Supremo Tribunal Federal (Tribunal Pleno). Referendo na Medida Cautelar na Ação Direta de Inconstitucionalidade 6.431/DF. Relator: Min. Marco Aurélio. Relator para o acórdão: Min. Edson Fachin, 15 de abril de 2020. Disponível em: https://redir.stf.jus.br/paginadorpub/paginador. jsp?docTP=TP\&docID=754372183. Acesso em: 26 nov. 2021.

BRASIL. Supremo Tribunal Federal (Tribunal Pleno). Referendo na Medida Cautelar na Arguição de Descumprimento de Preceito Fundamental 672/DF. Relator: Min. Alexandre de Moraes, 13 de outubro de 2020. Disponível em: https:// redir.stf.jus.br/paginadorpub/paginador.jsp?docTP=TP\&docID $=754239592$. Acesso em: 26 nov. 2021. 


\section{Legislação citada}

BRASIL. Congresso Nacional. Senado Federal. Resolução no 43, de 21 de dezembro de 2001. Dispõe sobre as operações de crédito interno e externo dos Estados, do Distrito Federal e dos Municípios, inclusive concessão de garantias, seus limites e condições de autorização, e dá outras providências. Brasília: Senado, [2021]. Disponível em: https://legis.senado.leg.br/norma/582604. Acesso em: 25 nov. 2021.

BRASIL. [Constituição (1988)]. Constituição da República Federativa do Brasil de 1988. Brasília: Presidência da República, [2021]. Disponível em: http:// www.planalto.gov.br/ccivil_03/Constituicao/Constituicao.htm. Acesso em: 25 nov. 2021.

BRASIL. Decreto no $\mathbf{1 0 . 2 8 2}$, de 20 de março de 2020. Regulamenta a Lei no 13.979 , de 6 de fevereiro de 2020, para definir os serviços públicos e as atividades essenciais. Brasília: Presidência da República, [2021]. Disponível em: http://www.planalto.gov.br/ccivil_03/_ato2019-2022/2020/decreto/D10282. htm. Acesso em: 25 nov. 2021.

BRASIL. Decreto no 10.292, de 25 de março de 2020. Altera o Decreto no 10.282, de 20 de março de 2020, que regulamenta a Lei no 13.979, de 6 de fevereiro de 2020, para definir os serviços públicos e as atividades essenciais. Brasília: Presidência da República, [2021]. Disponível em: http://www.planalto.gov.br/ ccivil_03/_ato2019-2022/2020/decreto/D10292.htm. Acesso em: 25 nov. 2021.

BRASIL. Lei Complementar no 101, de 4 de maio de 2000. Estabelece normas de finanças públicas voltadas para a responsabilidade na gestão fiscal e dá outras providências. Brasília: Presidência da República, [2021]. Lei de responsabilidade fiscal (LRF). Disponível em: http://www.planalto.gov.br/ccivil_03/leis/lcp/ lcp101.htm. Acesso em: 25 nov. 2021.

BRASIL. Medida Provisória no 926, de 20 de março de 2020. Altera a Lei $n^{\circ} 13.979$, de 6 de fevereiro de 2020, para dispor sobre procedimentos para aquisição de bens, serviços e insumos destinados ao enfrentamento da emergência de saúde pública de importância internacional decorrente do coronavírus. Brasília: Presidência da República, [2021]. Disponível em: https://www.planalto. gov.br/ccivil_03/_ato2019-2022/2020/mpv/mpv926impressao.htm. Acesso em: 25 nov. 2021. 